\title{
Öznelik yetisi: Bir göstergebilimsel çözümleme adımı ve çeviri göstergebilimi bakış açısıyla bir tiyatro metninde çeviri değerlendirmesi ${ }^{1}$
}

\section{Mesut KULELI'2}

\begin{abstract}
APA: Kuleli, M. (2018). Öznelik yetisi: Bir göstergebilimsel çözümleme adımı ve çeviri göstergebilimi bakıs açısıyla bir tiyatro metninde çeviri değerlendirmesi. RumeliDE Dil ve Edebiyat Araștırmalar Dergisi, (13), 33-72. DOI: 10.29000/rumelide.504251
\end{abstract}

$\ddot{\mathbf{O} z}$

Bu çalışmanın amacı, Shakespeare'in Macbeth oyununu Öztürk Kasar (2009) tarafından çeviri göstergebilimi çerçevesinde derlenen yazınsal metinlerde göstergebilimsel çözümleme adımlarından öznelik yetisi bakımından çözümlemek ve oyundaki yükümsüz özne içeren bağlamların dört Türkçe çevirisini çeviri göstergebilimi bakış açısıyla değerlendirmektir. Bu amaca yönelik olarak, JeanClaude Coquet (1997; 2007) tarafından öne sürülen “Söyleyenler Kuramı” ışığında yükümsüz özne olarak saptanan bağlamlar, Öztürk Kasar'ın (2017) Coquet'den benimseyerek çeviri göstergebilimi çözümlemesi için oluşturduğu Yükümsüz Özneler Tipolojisi’ne göre sınıflandırılmıştır. Ayrıca, yükümsüz özne içeren bağlamlarda söyleyenin Coquet'nin sınıflandırmasına göre (Öztürk Kasar, 2012; 2017) hangi bileşenin etkisinde olduğu bulunmuştur. Çeviri göstergebilimi bakış açısıyla çeviri değerlendirmesi için Öztürk Kasar'ın (Öztürk Kasar ve Tuna, 2015) Çeviride Anlam Bozucu Eğilimler Dizgeselliği kullanılmıştır. Çeviri değerlendirmesi sonucunda, Türkçe çeviri metinlerde de özgün metindeki yükümsüz öznelik durumu içeren bağlamların bir kısmında yükümsüz özneliği gösteren göstergeler korunuyorken, bazı bağlamlarda özgün metindeki yükümsüz öznelik durumunun Türkçe çeviriye yansımadığı, anlam bozucu eğilimlerin yer aldığı bulunmuştur. Çeviri göstergebilimi, bir çeviri eleştirisi modeli değil, bir metin çözümleme modeli olarak ortaya çıkmıştır ve var olan ve gelecekteki yazın çevirmenleri için bir ışık görevi görmektedir. Öztürk Kasar’ın (2009) ifade ettiği gibi çeviri göstergebilimi söylem düzeyinde okur ve çevirmene, söylemlerarası düzeyde çevirmen ve editöre, söylemüstü düzeyde ise çeviri araştırmacılarına katkıda bulunur. Anlam bozucu eğilimler yazın çevirmenleri tarafından her zaman kaçınılması gereken durumlar olarak değil, bazen de çevirmenlere anlam tuzaklarının nasıl üstesinden gelinebileceğine ışık tutan durumlar olarak görülmelidir.

Anahtar kelimeler: Öznelik yetisi, çeviri göstergebilimi, çeviri, söyleyenler kuramı, yükümsüz özne.

\section{Subjectivity: a step of semiotics of translation and translation evaluation of a play from semiotics of translation point of view}

\begin{abstract}
The purpose of this study is to analyze subjectivity in the play Macbeth by Shakespeare based on the semiotics analysis steps compiled by Öztürk Kasar (2009) in the framework of semiotics of translation and evaluate four Turkish translations of the contexts with "non-subjects" in light of

Part of this paper was presented as an oral presentation at Düzce University International Conference on Language (DUICOL / WRITING - 2018) held on 18-20 October, 2018.

2 Dr. Öğr. Üyesi, Bandırma Onyedi Eylül Üniversitesi, Bandırma Meslek Yüksekokulu, (Balıkesir, Türkiye), mkuleli@bandirma.edu.tr, ORCID ID: 000o-0002-3477-0412 [Makale kaylt tarihi: 30.10.2018-kabul tarihi: 22.12.2018; DOI: $10.29000 /$ rumelide.504251]
\end{abstract}


Subjectivity: a step of semiotics of translation and translation evaluation of a play from semiotics of translation point of view / M. Kuleli (p. 33-72)

\begin{abstract}
semiotics of translation. To this end, the contexts with "non-subjects", determined according to the "Theory of Instances" by Jean-Claude Coquet (1997; 2007), were further categorized based on "Typology of Non-subjects" adopted and compiled by Öztürk Kasar (2017) for semiotics of translation analysis. The components influential on the instances in contexts with non-subjects were determined based on Coquet's (in Öztürk Kasar, 2012; 2017) categorization of components. "Systematics of Designficative Tendencies in Translation” by Öztürk Kasar (in Öztürk Kasar and Tuna, 2015) was adopted for translation evaluation of the contexts with non-subjects. The findings of the translation evaluation showed that while the signs pointing to the non-subject state of the instances were preserved in certain contexts in the translated texts, it was not an infrequent condition that the signs implying the non-subject state of the instances were not transferred into the translated texts, with designificative tendencies coming to the fore. Semiotics of translation is a text analysis model rather than translation criticism, and it sheds light on literary translation for professional and potential literary translators. As posited by Öztürk Kasar (2009), semiotics of translation could be to the benefit of readers and translators in discourse level; translators and editors in inter-discourse level; scholars in translation studies in meta-discourse level. Designificative tendencies are not something to be evaded by literary translators all the time, but rather they might be instrumental in guiding literary translators to overcome the pitfalls and traps in the meaning universe of literary texts at times.
\end{abstract}

Key words: Subjectivity, semiotics of translation, translation, Theory of Instances, non-subject.

\title{
1. Giriș
}

Göstergebilim, 1913 yılında hayatını kaybeden Ferdinand de Saussure ve 1914 yılında hayatını kaybeden Charles Sanders Peirce tarafından hayattayken birbirlerinden habersiz ve bağımsız bir biçimde öne sürülmüş bir bilim alanıdır. Türkçede "göstergebilim" adıyla kullanılan bu alan, dünya literatüründe "semiotics (İngilizce), sémiotique (Fransızca)" ve "semiology (İngilizce), sémiologie (Fransizca)" adlarıyla karşımıza çıkmaktadır. Görüldüğü gibi Anglofon ve Frankofon literatürde iki farklı ismi olan bu alan, Türkçede sadece "göstergebilim" adıyla karşılık bulmuştur. Hawkes’a (1977) göre hem semiotiks hem de semioloji göstergebilim anlamına gelip aynı şeyi ifade ediyorken, "semioloji” Saussure tarafindan, "semiotiks" ise Peirce tarafından kullanılan terimlerdir. Coquet ve Öztürk Kasar (2003), Türkçede aynı karşılık ile kullanılan bu iki farklı terimin arasında 197olerden bu yana kullanımda bir nüans ortaya çıkmaya başladığını öne sürmüşlerdir. "Sémiologie denildiğinde, ...daha toplumsal içerikli, göstergenin toplum içindeki yaşamını inceleyen..., sémiotique denildiğindeyse, daha çok anlamlama olgusunu ..., anlamlama dizgelerini inceleyen dal anlaşllıyor" (Coquet ve Öztürk Kasar, 2003: s. 133). Buna rağmen, günümüzde Türkçede bu iki farklı terim aynı karşlık (göstergebilim) ile kullanılmaktadır.

Saussure (2001), bir dil göstergesinin "bir nesneyle bir adı" değil, "bir kavramla bir işitim imgesini" (s. 107) birleştirdiğini ifade etmiştir. Bu önermeye göre, "masa" objesi bir kavram iken, m-a-s-a ses birimlerinden oluşan kelime karşıllğı bir işitim imgesidir. "Bütünü belirtmek için gösterge sözcüğü kullanılmal, kavram yerine gösterilen ve işitim imgesi yerine de gösteren terimleri benimsenmelidir" (ibid, s. 109). Saussure'ün (2001) bu tanımlarına göre; kare, yuvarlak veya dikdörtgen gibi çeşitli şekillerde ve boyutlarda görebileceğimiz "masa" objesi gösterilen, m-a-s-a ses birimleri bir araya geldiğinde gösteren, gösterilen ve gösterenin birleşimi de gösterge olmaktadır. "Göstergelerin toplum yaşamı içindeki yaşamını inceleyecek bir bilim" olarak "göstergebilim diye adlandırılacak" bir bilimin ortaya çıkacağını ve bu bilimin "göstergelerin ne olduğunu, hangi yasalara bağlandığını" (ibid, s. 46) inceleyeceğini müjdeleyen Saussure, göstergebilimi geniş bir bilim alanı olarak görmüş ve dilbilimi, göstergebilimin bir alt kolu olarak nitelemiştir. 
Dilbilimi dahi içine alacak kadar geniş çaplı tasarlanan göstergebilim alanının, pek çok bilim alanı ile ilişki içinde olması olağan bir durum olarak düşünülebilir. Morris (1938) "dilbilimciler, mantık bilimciler, filozoflar, psikologlar, biyologlar, antropologlar, psikopatologlar, estetik bilimciler ve toplum bilimcilerden oluşan araştırmacı ordusunun" (s. 77) göstergebilimden yararlanarak kendi alanlarındaki göstergeleri incelediğini, bu durumun da göstergebilime disiplinlerarası bir nitelik kattığını belirtmiştir. $\mathrm{Bu}$ önerme, göstergebilimin çok geniş çapta bilim alanı ile ilişki içinde olduğunu göstermektedir. Nöth (1995) ise göstergebilimin Morris tarafından sayılandan çok daha fazla bilim alanı ile ilişki içinde olarak disiplinlerarası bir kimliğe bürünmüş olduğunu ifade etmiştir. Eco (1978), göstergebilimin tekil bir bilim olmaktan ziyade "disipilinlerarası bir yöntem veya yaklaşım" olarak görülebileceğini öne sürmüştür (s. 83). Hodge (1988) "social semiotics" (toplumsal göstergebilim) terimini öne sürerek sosyal bilimlerin göstergebilim ile ilişkili olduğunu ve çözümleme yöntemlerinde göstergebilimin yöntemlerinden faydalandıklarını ifade etmiştir. Göstergebilimin "yayılımcı (imperialist) ve en geniş çaplı bilim alanı olarak görüldüğünü" öne süren Suhor (1992: s. 228), "göstergebilimin disiplinlerarasıllğa temel oluşturan kapsayıcı bir kavram” (ibid, s. 229) olduğunu belirtmiştir. Valsiner ve Gertz (2007) "göstergebilim ve diğer bilim alanları arasındaki çakışmaya odaklanarak çeşitli anlamlama sorunlarına disiplinlerarası bir yaklaşım” (s. 198) sergilenebileceğini, böylece göstergebilimin disiplinlerarası bir özelliğe sahip olduğunu ifade etmiştir.

\title{
1.1. Çeviri göstergebilimi
}

Bu kadar çok bilim alanı ile ilişki içinde disiplinlerarası bir nitelikte olan göstergebilimin, çeviribilim ile olan ilişkisi de çeşitli kuramcılar tarafından öne sürülmüştür. Çeviri ile göstergebilim ilişkisini ele alan ilk önermelerden biri Ludskanov (1975) tarafından öne sürülmüştür. "Çevirideki yeni sorunlar çeviri sürecine göstergebilimin uygulanması ile aşılabilir ve göstergebilimsel dönüşümler bir bilgiyi şifreleyen göstergelerin, değişmeyen bilgiyi koruyarak başka şifreler ile yer değiştirmesidir (Ludskanov, 1975: s. 5). Bu önermeye göre, çeviri işlemi gerçekte bir dildeki göstergenin anlamının korunarak başka bir dildeki gösterge ile yansıtılmasıdır. "Çeviri ikincil bir göstergebilim sürecidir ve insanoğlunun doğuştan gelen şifreleme özelliğine dayanır” (Frawley, 1984: s. 160). Göstergebilim, en basit ve yalın haliyle "göstergeleri inceleyen bilim" (Mick, 1986: s. 196) olarak tanımlandığında, çevirinin bir göstergebilim süreci olarak görülmesi önermesi çevirinin aslında göstergeleri inceleyen ve onların şifrelerini çözen, bu şifreleri erek bir dilde yeniden üretme süreci olduğunu ima etmektedir. Siskin (1987), "çeviride dilbilimsel eşdeğerliğin çeviri göstergebilimi kuramıyla” (s. 129) ele alınabileceğini belirtmiştir. Torop (2001), Siskin gibi çeviri göstergebilimi kavramı üzerine yoğunlaşmıştır ve şunu önermiştir:

\begin{abstract}
"Çeviri göstergebilimi nispeten genç bir disiplinlerarası alandır ve ya çeviribilimde ya da göstergebilimde baskın olabilir. Çeviribilimin bir parçası olarak çeviri göstergebilimi dilbilimsel bakış açısıyla başlayıp çeviri metnin kültürel bir metin olarak işlev göstergemesiyle sona eren çevrilebilirlik konusunun farklı yönlerini inceler. Çeviribilim için metin çözümlemesinin göstergebilimsel yönü önemlidir. Göstergebilimin bir parçası olarak ise çeviri göstergebilimi gösterge dizgelerinin karşılaştırmalı çözümlemesiyle ve gösterge dizgileri arasındaki işlevsel bağlantılarla ilişkilidir." (Torop, 2001: s. 46).
\end{abstract}

$\mathrm{Bu}$ önermeye göre çeviri göstergebilimi alanı hem çeviribilime hem de göstergebilime katkıda bulunabilir. Ayrıca bu önermede geçen "çevrilebilirlik" sorunsalı kelimelerin veya cümlelerin değil, göstergelerin bir dilden diğer bir dile çevrilebilmesi açısından ele alınmaktadır. Özgün metindeki bir göstergenin veya göstergelerin erek metne transfer edilebilmesini mümkün kılacak olan çözümleme için, göstergebilimsel çözümleme öne sürülmüştür. "Özgün metin ile çeviri metin arasındaki ilişkiyi yorumlayıcı gösterge ve yorumlanan gösterge arasındaki ilişki” olarak gören Petrilli de (2007: s. 311), "göstergebilim yaklaşımının çeviri kuramının merkezi sorunsalı olan çevrilebilirlik üzerine ışık 
Subjectivity: a step of semiotics of translation and translation evaluation of a play from semiotics of translation point of view / M. Kuleli (p. 33-72)

tuttuğunu” (İbid, s. 311) belirtmiştir. Torop (2008), o ana kadar dile getirilen göstergebilim ve çeviribilim arasındaki ilişkiye dair kapsamlı bir öneri yapmıştır:

\begin{abstract}
“Çeviri göstergebilimi tek başına bir bilim alanı olma yolunda ilerliyor... Çeviribilim ve göstergebilim arasındaki ilişkiyle evrilen bir bilim alanı olan çeviri göstergebiliminin kimliği, karşılıklı etkilenmeler ile anlaşılabilir. Çeviribilim zaten uzun zamandır göstergebilimden yararlanmaktadır... Bu iki disiplin arasındaki karşılıklı ilişkinin yanı sıra, [çeviri göstergebiliminin] disiplinlerarası yönü de önemlidir” (Torop, 2008: s. 253).
\end{abstract}

$\mathrm{Bu}$ önermeden de çeviribilimin göstergebilimden faydalanabildiği görülmektedir. Göstergebilimin kapsayıcı disiplinlerarası yöntemi ve kuramı çeviribilimi de etkilemiştir. Göstergebilimin çeviriye ve çeviribilime katkısı pek çok araştırmacı tarafından öne sürüldükten sonra, bu çalışma yazın çevirisi üzerine yoğunlaştığı için bu noktadan itibaren göstergebilimin yazın çevirisine katkısı üzerine durulacaktır.

\title{
1.1.1. Yazın çevirisi için çeviri göstergebilimi
}

Öztürk Kasar (2009), göstergebilimin çeviri edimine büyük bir katkısı olduğunu ifade ederken daha çok edebi bir metnin çevirisindeki göstergebilim katkısı için;

\begin{abstract}
"Bir edebi metin çözülmesi gereken göstergeler evrenidir: çevirmeden önce bu göstergelerin nasıl okunması gerektiği bilinmelidir çünkü bu göstergeler ilk bakışta kendilerini açı̆̆a vurmazlar. Edebiyat alanında göstergebilim, okur, editör, yayımcı, edebiyat eleştirmeni veya göstergebilim çözümlemecisi için, dolayısıyla metinde anlam arayışı içinde olan herkes için bir okuma ve çözümleme modeli sağlar” (Öztürk Kasar, 2009: s. 164).
\end{abstract}

ifadeleri ile yazın çevirisinde göstergebilimin hangi boyutta ve derinlikte yardımcı olabileceğini belirtmiştir. Paris Göstergebilim Okulu'nun metin çözümleme adımlarını çeviri göstergebilimine uygulayan ve uyarlayan Öztürk Kasar (2009), çeviri ediminden önce özgün metnin çözümlenmesinde bu adımları önermiştir.3 "Göstergebilimin birincil sorunsalı aynı zamanda çeviribilimin de birincil sorunsalıdır. Her ikisi de anlamın yakalanması ve yeniden üretilmesiyle ilgilenir... ama edebi metinlerde anlam kendini hemen ele vermez, yazarın söylem tekniklerinin oluşturduğu bir süreçten geçer" (ibid, s. 165). Buna göre çevirmenin ve gösterbilimcinin görevleri birbirine benzemekle beraber, edebi metinlerdeki anlam oluşumunu yeniden üretmek görevi üstlenen edebi çevirmen, aynı zamanda iyi bir gösterge okuru ve çözümleyicisi olmalıdır. Öztürk Kasar’ın (2009) önerdiği çözümleme adımlarından "söyleyenlerin öznelik dönüşümleri” (ibid, s. 169). adımı bu çalışmada kullanılmıştır. "Tüm adımlar bir metinde bulunamayabileceğinden dolayı, metnin anlam evrenine ulaşmak için tüm adımları kullanmanın yanı sıra bu adımlardan sadece birini veya birkaçını kullanmak da mümkün olabilir” (Tuna ve Kuleli, 2017: s. 43). "Söyleyenlerin öznelik dönüşümleri” Jean-Claude Coquet'nin (1997; 2007) “Söyleyenler Kuramı” dahilindeki bir kavramdır. Coquet'ye (2007) göre bir söyleyen eğer yargının varlığı konumunda söylemini üretebiliyorsa "sujet” (özne); yargının yarı varlığı konumunda, yani yarı bilinç durumunda söylemini üretiyorsa "quasi-sujet” (eşik özne); yargı yokluğu durumunda söylem üretiyorsa "non-sujet” ( s. 37) (yükümsüz özne)4 olarak sınıflandırllabilir. "Yargılama yeteneği, öznenin hangi durumda olduğunun belirleyicisidir" (Öztürk Kasar, 2009: 169). "Yükümsüz özne söylemleri, çözümlemesi özellikle ilginç söylemlerdir, genellikle tutkusal boyuta işaret ederler” (ibid, s. 169). Bu yüzden bu çalışmada Shakespeare’in Macbeth oyunu çözümlenirken özellikle hırs, kıskançlık, öfke,

\footnotetext{
3 Çeviri göstergebilimi yöntemiyle edebi metin çevirisi amaçlı özgün metnin çözümlenmesinde kullanılabilecek adımlar için bkz. Öztürk Kasar, 2009: s.166-172.

$4 \quad$ Coquet'nin bu kavramları, Öztürk Kasar (2012) tarafından Türkçeye çevrilmiştir.
} 
korku gibi tutkular öne çıttı̆̆ için ve tutkular bu metindeki egemen unsurlar olduğu için sadece öznelik dönüşümleri incelenmiştir.

Öztürk Kasar (2017) "eşik özne” kavramı için "gece yarısı çalan bir telefonla yataktan fırlayan” (s. 190) yarı bilinç durumundaki ama henüz davranışlarının ve söylemlerinin tam bilincinde olmayan bireyi örnek göstermiştir. "Yükümsüz özne" kavramını çeviri göstergebilimine uyarlayan Öztürk Kasar (2017) yükümsüz özneleri sekize ayırmıştır:

“i. Doğa gereği bilinç yokluğu ya da yetersizliği: Küçük yaştaki çocuklar...

ii. Patolojik bir durumdan kaynaklanan bilinç eksikliği: Akıl hastaları, Alzheimer gibi... hastalıklara maruz kalanlar, uyurgezerler, şizofrenler...

iii. Kimi tedavi amaçlı maddelerin etkisiyle bilinç dışına çıkma: Anestezi altındaki hasta... bilinçsiz sayılamalar...

iv. Kimi kimyasal maddelerin etkisiyle bilinç dışına çıma: Sarhoşlar, ayyaşlar, ...uyuşturucu ya da bağımlılık yaratan madde kullananlar.

v. Bedensel dengesizlik durumları.

a) İtkiler türündeki içkin bileşenden kaynaklanan durumlar: Halüsinasyonlara ve saylklamalara neden olan uzun süreli açlık ve susuz kalma durumu, bedenimizde hormon düzeyinin değişmesiyle ortaya çıkan her türlü rahatsızlıklar.

b) Tutkular türündeki içkin bileşenden kaynaklanan durumlar:

* Esenlikli durum (haz): Çok büyük coşku, heyecan ve sevinç durumu...

* Esenliksiz durum (elem): İnsanı gerçeklikten uzaklaştıran ... fiziksel ya da ruhsal aclar... intihar edenler.

* Ne esenlikli ne esenliksiz durum: ...coşku kökenli olmayan bedensel dengezilik durumu... araba tutması... lunaparklardaki hızla döndüren araçların yarattığı baş dönmeleri...hız sarhoşluğu...

c) Kozmik nitelikteki bir aşkın bileşenden kaynaklanan bedensel dengesizlik durumu: Kozmik olaylar, deprem, kasırga, tsunami...insanı etkileyen her türlü atmosfer ve iklim olgusu...çıldırtan sıcaklar, Föhn rüzgarları..

vi. Aşkın bir bileşene boyun eğme durumu.

a) Az ya da çok içselleştirilmiş sembolik nitelikte bir aşkın bileşene boyun eğme: Tanrı, din, genel kabulleriyle toplum, bazı ülkelerde parti vb., kan davası / namus cinayetleri... politik, ideolojik, dinsel bir davaya inanıp intihar saldırısı düzenleyen kamikazeler.

b) Korku salan ya da işkence eden baskın nitelikte bir aşkın bileşene boyun eğme: Korkudan ya da daha fazla direnemeyerek kendi iradesinden vazgeçme...

c) Söyleyenin iradesi üzerinde etki eden bir bileşene boyun eğmesi: Hipnoz...trans hali...

vii. Robotlaş(tırll)mış özne: Coquet, bir başkasının düşüncelerini, sözlerini papağan gibi tekrarlayan kişilere 'sahibinin sesi' adını verir. Araba kullanırken düşüncelere dalıp 'otomatik pilota bağlamak' ve kendimizi gitmek istediğimiz yerde bulmak.

viii. Bir işleve indirgenmiş kimlik: biçim-özne.

a) Kurumsal biçim-özne: Kurumsal bir biçimde politik, dinsel vb. bir misyona kendini adayıp her türlü başka yaşantıdan vazgeçenler...

b) Bireysel biçim-özne: Bireysel olarak... bir amaç uğruna her şeyden vazgeçenler. 
Subjectivity: a step of semiotics of translation and translation evaluation of a play from semiotics of translation point of view / M. Kuleli (p. 33-72)

(Öztürk Kasar, 2017: s. 191-194)

Öztürk Kasar (2017) bu sınıflandırmayı "Yükümsüz özneler sınıflandırması" (s. 190) olarak adlandırmıştır. Bu sınıflandırmada yer alan tüm kategoriler ve örnekler kendi söylemini üstlenemeyen, yargı ve bilinç durumunda olmayan yükümsüz öznelerdir. "Jean-Claude Coquet söylem üreticisinin dört bileşenden oluştuğunu düşünmektedir” (ibid, s. 187). Öztürk Kasar (2012; 2017) Coquet'nin öne sürdüğü söyleyenin bileşenlerini yükümsüz özneler sınıflandırması amaçlı derlemiştir. Bu bileşenler "temel bileşen, kavramlaştırıcı bileşen, içkin bileşen ve aşkın bileşen" (Öztürk Kasar, 2017: s. 187) olarak adlandırılmıştır. "Temel bileşen bedenimizdir...beş duyumuz aracıllğıyla dünya içimize girer" (ibid, s. 188). Coquet'nin bedene verdiği bu önem, onu görüngübilime yaklaştırmıştır ve Merleau-Ponty'nin görüngübilim düşüncelerinden etkilendiğini gösterir (Öztürk Kasar, 2012). Bu temel bileşen, yani bedenimiz olmasa hiçbir dış uyarıcıyı algılayamaz duruma geliriz ve özne olarak var olamayız. Bu beş duyu yoluyla "algılamış olduklarımızı da bir süzme işleminden geçirdikten sonra değerlendirmesi için kavramlaştırıcı bileşene, yani aklımıza iletiriz. Akıl... algılanan olguyu yeniden ele alarak yargılar"(Öztürk Kasar, 2017: s. 188). Coquet'ye göre temel bileşen ve kavramlaştırıcı bileşen "söyleyenin özerklik alanını oluştururlar" (ibid, s. 188). Temel bileşeni ve kavramlaştırıcı bileşeni etkin ve işlevsel durumda olan bir söyleyen, Coquet'nin söyleyenler tipolojisine göre "özne” olarak sinıflandırılabilir. Söyleyen, özne konumundayken yargı durumunda bulunduğu için bu ilk iki bileşen "özerklik alanı" şeklinde adlandırılmış olabilir. "İçkin bileşen bedenimizin içine yerleşmiş olan ve bizi içerden esir alan güçlerdir... itkiler ve tutkular olarak ikiye ayrılır" (ibid, s. 188). İtkiler "biyolojik ve fizyolojik güçler: açlık, susuzluk, saldırganlık, cinsellik, hayatta kalma içtepisi” (ibid, s. 188) olarak tanımlanırken, tutkular "aşk, sevgi, hırs, kıskançlık, öfke, korku, merak" (ibid, 188) gibi duygular olarak örneklendirilmiştir. Son olarak, aşkın bileşen "...insanı aşan, üzerimize yerleşen ve bizi güdümleyen güçler” (ibid, s. 188) olarak tanımlanırken, "yaşadığımız evrenin güçleri olan kozmik güçler” (ibid, s. 188) ve "din, ahlak, hukuk, toplumsak tabular, gelenek ve görenekler, adetler...gibi...insan düşüncelerini baskılayan simgesel güçler" (ibid, s. 189) olmak üzere ikiye ayrılmıştır. İçkin bileşen ve aşkın bileşen ise söyleyenin "bağımlılık alanı"nı (ibid, s. 188) oluşturular. Söylem esnasında söyleyen kavramlaştırıcı bileşenin değil, içkin bileşen veya aşkın bileşenin etkisine girdiğinde yükümsüz özne olması beklenir çünkü yargı yokluğuyla bir söylem üretmektedir ve söyleyeni kendi özerkliğinden uzaklaştırmaktadır.

\subsubsection{Yazın çevirisi değerlendirmesi için anlam bozucu eğilimler}

Özgün metin üzerinde göstergebilim çözümlemesi sonrası yapılabilecek yazın çevirisi için Öztürk Kasar (Öztürk Kasar ve Tuna, 2015) çevirmenler, editörler ve çeviribilim araştırmacaları için çeviri değerlendirmesi amaçlı Çeviride Anlam Bozucu Eğilimler Dizgeselliğini (s. 463) öne sürmüştür. Bu dizgesellik bir çeviri eleştirisi modeli olarak değil, profesyonel yazın çevirmenleri ve gelecekteki yazın çevirmenleri için bir çeviri değerlendirme dizgeselliği olarak oluşturulmuştur. Öztürk Kasar’ın dizgeselliğindeki eğilimler şöyledir:

“i. Anlamın aşırı yorumlanması: Özgün yapıttaki anlama ilişkin aşırı bir yorum sunmak. Sonucunda aşırı çeviri / aşırı anlam ortaya çıkar.

ii. Anlamın bulanıklaştırılması: Özgün yapıtta açık seçik bir biçimde dile getirilmiş bir anlamı bulanık, belirsiz hale getirmek. Sonucunda bulanık anlam ortaya çıar.

iii. Anlamın eksik yorumlanması: Özgün yapıttaki bir gösterge veya göstergeler için eksik bilgi vermek, yetersiz anlam üretmek. Sonucunda eksik çeviri / yetersiz anlam ortaya çıar.

iv. Anlamın kaydırılması: Bir söz birimin potansiyel olarak içinde taşıdığı ancak özgün metin bağlamında gerçekleşmemeiş bir anlamı üretmek. Sonucunda başka anlam ortaya çıkar. 
v. Anlamın bozulması: Özgün metindeki anlamla tümüyle ilintisiz olmamakla birlikte yanlış bir anlam üretmek. Sonucunda yanlış anlam ortaya çıkar.

vi. Anlamın çarpıtılması: Özgün metindeki anlama zıt bir anlam üretmek. Sonucunda karşıt anlam ortaya çlkar.

vii. Anlamın saptırılması: Özgün metindeki anlamla hiçbir ilintisi olmayan bir anlam üretmek. Sonucunda aykırı anlam ortaya çıkar.

viii. Anlamın parçalanması: Anlamdan yoksun bir sözce üretmek. Sonucunda anlamsızlık ortaya çlkar.

ix. Anlamın yok edilmesi: Özgün metinde anlam üreten bir birimin çeviri metinde silinmesi. Sonucunda çeviri yokluğu ve gösterge yokluğu ortaya çıkar.

(Öztürk Kasar ve Tuna, 2015: s. 463).

$\mathrm{Bu}$ dizgesellikteki anlamın aşırı yorumlanması, anlamın bulanıklaştırılması ve anlamın eksik yorumlanması eğilimleri Öztürk Kasar (Öztürk Kasar ve Tuna, 2015) tarafından "göstergenin anlam alanı içerisinde" (s. 463); anlamın kaydırılması, anlamın bozulması ve anlamın çarpıtılması eğilimleri "göstergenin anlam alanının sınırlarında" (ibid, s. 463); anlamın saptırılması, anlamın parçalanması ve anlamın yok edilmesi eğilimleri ise "göstergenin anlam alanının dışında" (ibid, s. 463) olarak sınıflandırılmıştır. Bu durumda, ilk üç anlam bozucu eğilimde, erek metindeki söylemlerde özgün metindeki anlam devam etmektedir. Göstergenin anlam alanının sınırlarındaki eğilimlerde, erek metindeki söylem özgün metindeki söylemin anlamından biraz uzaklaşmasına rağmen halen "dolay anlam" (ibid, s. 463) ortaya çıkmaktadır. Son üç anlam bozucu eğilimde ise erek metindeki söylem, özgün metindeki söylemin anlamı dışına çıkmıştır.

\section{Yöntem}

Bu bölümde, veri toplama araçları ve veri toplama ve analizi yöntemi verilmiştir.

\subsection{Veri toplama araçları}

Çalışmanın özgün metin üzerindeki göstergebilim çözümlemesinde Shakespeare'in "1606 yllında yazdığına inanılan” (Brooke, 2008: s. 59) ve ilk defa “1623’te First Folio'da basılan....ancak bu basımda yapısal problemleri göze çarpan” (ibid, s. 49) özgün Macbeth oyununun 1994'te Penguin Books Yayınevi tarafından yapılan kısaltılmamış basımı kullanılmıştır. Brooke'a (2008) göre Shakespeare bu oyunu yazarken "Holinshed'in 1587 yllında basllan Chronicle of Scotland" (s. 67) tarih yazımindan yararlanmıştır. Oyun, üç cadının konuşmalarıyla ve İskoçya Kralı Duncan'ın kazandıkları zafer sonucunda Macbeth'e övgüleriyle başlar. Üç cadı, İskoçyalı bir soylu olan Macbeth'e yakında Cawdor Beyi, sonra da kral olacağını müjdeler. Aynı uzamda diğer bir İskoçyalı soylu olan Banquo'ya ise geleceğin kralının babası olacağını müjdeler. Cawdor Beyi savaşta ülkesine ve Kral Duncan'a ihanet ettiği için görevinden alınır ve Macbeth bu müjdeden sonra Cawdor Beyi olduğunu öğrenir. Önceleri cadılara inanmak istemese de bu gelişme Macbeth’i heyecanlandırır. Karısı Lady Macbeth'e bir haberci yoluyla bu haberleri bildirir. Bu haberler karşısında büyük bir haz içine giren Lady Macbeth, kocası Macbeth evine döndüğünde ertesi gün Kral Duncan'ın onları ziyarete geleceğini duyunca Duncan'ın ölmesi ve kocası Macbeth’in kral olması için kanlı planlar tasarlamaya başlar. Macbeth her ne kadar bu planlar karşısında endişelere kapılsa ve bu planları uygulamak istemese de, Lady Macbeth'in ısrarlı ikna çabaları sonrası bu planın bir ortağı olur ve Kral Duncan'ın onları ziyaret ettiği ve onlarda kaldığı gece Macbeth Duncan'ı öldürür. Diğer soylular ve Duncan'ın oğulları sabah kralın yanına geldiğinde babalarının ölmüş olduğunu gördüğünde ise, Macbeth karısı Lady Macbeth’in planı dahilinde suçu Duncan'ın korumaları olan iki sarhoş askere atar ve onları öldürür. Uzamdaki pek çok karakter buna 
Subjectivity: a step of semiotics of translation and translation evaluation of a play from semiotics of translation point of view / M. Kuleli (p. 33-72)

inanırken, Duncan'ın oğulları Malcolm ve Donalbain buna inanmazlar ve ölüm sırasının kendilerine geldiğine inanarak İskoçya'yı terk ederler. Duncan'ın ölmesiyle Macbeth İskoçya kralı olur ve cadıların kehanetinin doğru çıkması sonucu o gün yanında kral babası olacağı müjdelenen diğer bir soylu olan Banquo ve oğlu Fleance'ı, kendi verdiği bir yemek şöleni gecesi adamlarına öldürtmek ister. Adamları Banquo’yu öldürür ancak oğlu Fleance kaçar. Adamları şölene gelip Macbeth’e bunu haber verince Macbeth eleme bürünür ve yemek masasında kendi sandalyesinde Banquo'nun hayaletinin oturduğunu görür. Macbeth'in gördüğü bu hayaleti kimse görmediği için Macbeth’in davranışlarına anlam veremeyen konuklar, Lady Macbeth'in ısrarıyla şölenden erken çıkarlar. Bir gün yine cadılara danışan Macbeth, gökten inen birinci hayaletten "Beware Macduff" (Shakespeare, 1994: s. 77) cümlesi ile diğer bir İşkoçya soylusu olan Macduff'tan kendini koruması gerektiğini öğrenir. İkinci hayaletten ise "none of woman born / Shall harm Macbeth" (ibid, s. 77) cümleleri ile bir kadından doğan hiç kimsenin kendisine zarar veremeyeceğini işitince rahatlar. Sonuçta Macduff da bir kadından, bir anneden doğduğu için endişelenecek bir şey olmadığını düşünür. Üçüncü hayaletin de "Macbeth shall never vanquish'd be, until / Great Birnam Wood, to high Dunsinane Hill / Shall come against him" (ibid, s. 78) cümlesiyle büyük Birnam Ormanı’nın Dunsinane tepesine kadar yürümedikçe kendisini kimsenin yenemeyeceğini duyması üzerine, Macbeth bu kehanetleri kendisinin asla tahttan indirilemeyeği olarak yorumlar, sonuçta her insan bir kadından doğmuştur ve bir ormanın da tepeliğe doğru yürümesini imkansız olarak görür. Bu arada Macduff da İskoçya'yı terk eder ve Duncan'ın oğlu Malcolm'un yanına kaçar. Macbeth, Macduff'ın İskoçya'da kalan karısı ve çocuğunu öldürür. Bunu duyan Macduff, Malcolm ile birlikte İngiltere'de bir ordu toplayarak Macbeth'e saldırmaya karar verirler. Macbeth de ordusunu toplar ancak cadılara gittiği gün hayaletlerden öğrendiği kehanetler sebebiyle herhangi bir endişesi yoktur. Bu arada Lady Macbeth, geceleri uyurgezer olur ve uyku halindeyken bilinçsiz bir şekilde kalkar, yürür ve konuşur. Bir hekim getirirler ama nicelerini iyilşetiren hekim bile buna bir çözüm bulamaz. Başta Malcolm ve eski İskoçya soylusu Macduff'ın bulunduğu İngiliz ordusu, Macbeth’in ordusuna karşı savaşa doğru giderken Birnam Ormanı'na yaklaşınca asker sayılarının belli olmaması için Duncan'ın oğlu Malcolm her askerin ormandaki ağaçlardan birer dal alıp kafasına tutarak kendilerini kamufle etmelerini, böylece asker sayılarının karşı taraf tarafından yanlış sayılması için emir verir. Savaşı bekleyen Macbeth, karısı Lady Macbeth'in düştüğü bu hastalıktan öldüğünü duyar ancak o anda gelen haberci, Macbeth'e daha korkunç bir haber getirir. Birnam Ormanı'nı yürüken gördüğünü söyleyen haberci, Macbeth'te büyük bir endişe uyandırır zira hayalet bu orman yürümedikçe Macbeth'e bir şey olmayacağını söylemişti. Ağaç dallarıyla kamufle olan İngiliz ordusunun yaklaşması Birnam Ormanı'nın yürümesi kehanetini Macbeth'in beklentisinin tam tersine çevirmiştir. Macbeth elemden çlgına döner ama bir kadından doğan kimse onu öldüremeyeceği için halen rahattır. Savaşta Macduff ile karşı karşıya gelen Macbeth, Macduff'n "Macduff was from his mother's womb / Untimely ripp'd” (Shakespeare, 1994: s. 105) cümlesiyle Macduff'in annesinden doğmadan önce annesinin karnından yarılarak çıkarıldığını öğrenir ve diğer kehanetin de aleyhine çıktığını görüp Macduff ile savaşır, ancak oyunun sonunda Macduff, elinde Macbeth'in kellesiyle Malcolm’u kral ilan eder ve Duncan'ın oğlu Malcolm İskoçya'nın yeni kralı olur.

Çeviri değerlendirmesi için, Macbeth oyununun aynı başlıkla 1946, 1967, 2000 ve 2015 ylllarındaki farklı çevirmenler tarafından yapılan Türkçe çevirileri değerlendirilmiştir. Bu çalışmada bulguları ve sonuçları verirken 1946 basımı çeviri metin EM1 (erek metin 1); 1967 basımı çeviri metin EM2 (erek metin 2); 2000 basımı çeviri metin EM3 (erek metin 3) ve 2015 basımı çeviri EM4 (erek metin 4) olarak kodlanmıştır.

\subsection{Veri toplama ve analizi yöntemi}


Özgün metnin göstergebilimsel çözümlemesi için Öztürk Kasar (2009) tarafindan çeviri göstergebilimi amaçlı derlenen çözümleme adımlarından söyleyenlerin öznelik dönüşümleri incelenmiştir. Özgün metindeki öznelik dönüşümleri Coquet'nin (1997; 2007) söyleyenler kuramındaki “özne, eşik özne, yükümsüz özne" (Coquet, 2007: s. 37) sınıflandırmasına göre çözümlenmiştir. Yükümsüz özne söylemi saptanan bağlamlar, Öztürk Kasar'ın (2017) yükümsüz özneler sınıflandırmasına göre kategorize edilmiştir. Ayrıca, yükümsüz özne saptanan söyleyenlerin söylem esnasında Coquet’nin öne sürdüğü ve Öztürk Kasar’ın (2017) çeviri göstergebilimi amaçlı derlediği söyleyenlerin bileşenlerinden hangisinin etkisi altında bulunduğu çözümlenmiştir. Çeviri değerlendirmesi, Öztürk Kasar’ın (Öztürk Kasar ve Tuna, 2015) çeviride anlam bozucu eğilimler dizgeselliğine dayanarak yapılmıştır. Çeviri değerlendirmesinde, özgün metinde saptanan yükümsüz özne söylemlerinin çevirileri, Macbeth oyununun sahnelenmek üzere değil, bir edebi metin olarak çevrilmesi üzerine kurulmuştur.

Özgün metindeki yükümsüz özne içeren söylemler ve söyleyenin bileşenleri, sadece İngilizce özgün metin üzerinden çözümlenmiş ve analiz edilmiştir. Bu söylemler, öznelik dönüşümlerinin sıklı̆̆ını ve yükümsüz özneye dönüüşmeye neden olan olaylar arasındaki bağıntıyı daha iyi gösterebilmek amacıyla oyundaki kronolojik sıralamasına göre bulgular bölümünde verilmiștir. Yükümsüz özne saptanan özgün metindeki söylemlerin çözümlemesiyle çeviri metinlerdeki bu söylemlerin çevirileri birlikte verilmiştir.

\section{Bulgular}

Yükümsüz özne saptanan söylemlerin çözümlemesi ve bu söylemlerin Türkçe çevirilerinin değerlendirmesi bu bölümde verilmiştir.

Yükümsüz Özne Söylemi 1:

\section{“LADY MACBETH}

Come you spirits,

That tend on mortal thoughts, unsex me here,

And fill me from the crown to the toe, top-full

Of direst cruelty: make thick my blood,

Stop up th' access and passage to remorse,

That no compunctious visitings of Nature

Shake my fell purpose, nor keep peace between

Th' effect, and it. Come to my woman's breasts,

And take my milk for gall, you murth'ring ministers,

Wherever, in your sightless substances,

You wait on Nature's mischief. Come thick Night,

And pall thee in the dunnest smoke of Hell,

That my keen knife see not the wound it makes,

Nor Heaven peep through the blanket of the dark,

To cry, hold, hold.

(Shakespeare, 1994: s. 37-38).

Söylemdeki “...unsex me here, fill me ... of direst cruelty / Come to my woman's breasts, And take my milk for gall / ... my keen knife see not the wound it makes” (ibid, s. 37-38) göstergeleri, [“...alın benden 
Subjectivity: a step of semiotics of translation and translation evaluation of a play from semiotics of translation point of view / M. Kuleli (p. 33-72)

kadınlığımı; taşlaştırın beni / sarın memelerimde kadınlığımı, zehire çevirin sütümü / görmesin açacağı yarayı keskin hançerimin gözü bile” (Shakespeare, 2017: s. 19)] söylem üreticisi olan Lady Macbeth’in hırsından dolayı kavramlaştırıcı bileşeni kaybettiğini göstermektedir. Söylem, Macbeth’in cadılar tarafından krallıkla müjdelendiğinin ve bu gece Kral Duncan'ın onları ziyarete geldiğinin Lady Macbeth'e bir haberci tarafından haber verilmesiyle Lady Macbeth’in yaşadığı büyük bir coşku esnasında üretilmiştir. Söyleyenin, tutku kökenli içkin bileşenin kontrolü altında bu söylemi üretmiş olduğu düşünülebilir. Ayrıca, Öztürk Kasar’nn (2017) yükümsüz özneler sınıflandırmasına göre söyleyen bu söylem üretiminde esenlikli durumda tutkular türündeki içkin bileşenden kaynaklanan bedensel dengesizlik durumunda yükümsüz özneye dönüşmüştür. Yükümsüz özne saptanan bu söylemin Türkçe çevirileri aşağıdadır.

EM1

"LADY MACBETH

Kanlı niyetlere hizmet eden ruhlar! Gelin beni burada kadınlığımdan sıyırın da tepeden tırnağa, ağız ağıza zalimliklerin en müthişiyle doldurun! Kanımı dondurun, sefkatin yolunu tıkayın ki geçmesin de zaman zaman gönderdiği pişmanlık korkunç kararımı sarsmasın, sonuyle onun arasına girmesin. Ey cinayet elçileri, görünmez cisimlerinizle her nerede tabiata zarar vermiye bakıyorsanız, buraya, şu kadın göğsüne gelin, sütümü zehire çevirin! Gel, karanlık gece, cehennemin en koyu dumanına bürün ki keskin bıçağım açtığı yarayı görmesin; gök de karanlığı aralayıp bakarak "Dur! Dur!” diye haykırmasın."

(Shakespeare, 1946: s. 19-20).

EM2

"LADY MACBETH

Gelin cinlerim, kana susamış cinlerim!

Gelin, alın benden kadınlığımı;

Katılaştırın, taşlaştırın beni tepeden tırnağa.

Öyle koyulaştırın ki kanımı,

Merhamet işleyemez olsun içine!

İnsanlığım yumuşatıp da beni

Sarsmasın korkunç kararımı;

Aman vermeyin bana işim bitinceyedek!

Gelin, cinayet elçileri, gelin neredeyseniz,

Siz ey varlığım göze görünmez kötülük yılanları,

Gelin, sarın memelerimde kadınlığımı,

Zehire çevirin sütümü! Sen de gel, karanlık gece;

En kara cehennem dumanlarına sarın da gel,

Gel ki görmesin açacağı yarayı

Keskin hançerimin gözü bile.

Karanlık göklerden hiç bir ışık sızıp da

"Dur! Vurma!" diyemesin bana!"

(Shakespeare, 1967: s. 28).

EM3 


\section{"LADY MACBETH}

Ey düşüncelere eşlik eden cinler, gelin hadi,

Çekin alın kadınlığımı benden; baştan ayağa,

En haince gaddarlıkla doldurun içimi;

Kanımı koyulaştırın,

Vicdana giden yolları, geçitleri tıkayın,

Azap, merhamet duyguları yol bulup geçemesin,

Amansız planımdan caydıramasın beni,

Hedefimle benim arama dikilemesin.

Gelin, sütümü alın göğüslerimden,

Yerine safra koyun, ey katillerin aracisı ruhlar;

Görünmez varlığınızla, bir uğursuzluk çıksa diye

Nerelerde bekliyorsanız, çıkın ortaya!

Sen de, karanlık gece,

Cehennemin en koyu dumanına bürün de gel artık;

Gel ki, keskin bıçağım açtığı yarayı göremesin,

Gökler, o kalın örtünün ardında yapılanı seçip,

'Dur, yapma!' diyemesin."

(Shakespeare, 2000: s. 37-38).

EM4

\section{"LADY MACBETH}

Kanlı niyetime hizmet edecek cinler, gelin!

Gelin de, alın benden kadınlığımı,

Acımasızlı̆ı̆n en korkuncuyla

Doldurun beni tepeden tirnağa!

Kanımı dondurun, taşlaştırın yüreğimi;

Merhamet işleyemez olsun içime!

Zaman zaman gönderdiği pişmanlık

Sarsmasın korkunç kararımı;

İşim bitinceye kadar araya girmeyin!

Ölüm melekleri, memelerime gelin,

Sütümü zehire çevirin!

Görünmeyen cinler, siz de

Doğanın kötülüklerine bekçilik edin.

Sen de gel, ey karanlık gece,

Cehennemin en koyu dumanına bürün ki,

Keskin hançerimle açtığım yara görünmesin;

Gök de karanlı̆̆ı aralayıp

Bana 'Dur, vurma!' demesin.” 
Subjectivity: a step of semiotics of translation and translation evaluation of a play from semiotics of translation point of view / M. Kuleli (p. 33-72)

(Shakespeare, 2015: s. 36-37).

Özgün metindeki "Come you spirits, / That tend on mortal thoughts" (Shakespeare, 1994: s. 37) cümlesi, EM1'de "Kanlı niyetlere hizmet eden ruhlar! Gelin" (Shakespeare, 1994: s. 19) olarak; EM2'de "Gelin cinlerim, kana susamış cinlerim!” (Shakespeare, 1967: s. 28) olarak; EM3’te "Ey düşüncelere eşlik eden cinler, gelin" (Shakespeare, 2000: s. 37) olarak; EM4'te ise "Kanl niyetime hizmet edecek cinler, gelin!" (Shakespeare, 2015: s. 36) olarak çevrilmiştir. Özgün metindeki "mortal thoughts" göstergesi EM1'de "kanlı niyetler”, EM2'de "kana susamış cinler”, EM4’te "kanlı niyet” göstergesi ile Türkçeye çevrilmiştir. Bu çevirilerde, özgün metinde olduğu gibi söylem üreticisi yükümsüz özne olan Lady Macbeth'in coşku içinde Kral Duncan’ı öldürme planı çeviri metin okuruna yansıtılmıştır. Ancak EM3’te, kullanılan "düşünceler" göstergesinin niteleyicisi olan "mortal" göstergesi yok edilmiştir ve çeviri metin okuru bu söylemde Lady Macbeth’in Duncan’ı öldürme planı yapmakta olduğunu alımlayamamaktadır. Özgün metindeki anlam üreten bir birim çeviri metinde silindiği için, bu durum Öztürk Kasar’ın (Öztürk Kasar ve Tuna, 2015) dizgeselliğine göre anlamın yok edilmesi eğilimi olarak düşünülebilir.

Yükümsüz Özne Söylemi 2:

\section{"MACBETH}

Is this a dagger, which I see before me,

The handle toward my hand? Come, let me clutch thee:

I have thee not, and yet I see thee still.

Art thou not, fatal vision, sensible

To feeling, as to sight? or art thou but

A dagger of the mind, a false creation,

Proceeding from the heat-oppressed brain?

I see thee yet, in form as palpable,

As this which now I draw.

Thou marshall'st me the way that I was going,

And such an instrument I was to use.

Mine eyes are made the fools o' th' other senses,

Or else worth all the rest: I see thee still;

And on thy blade, and dudgeon, gouts of blood,

Which was not so before. There's no such thing:

It is the bloody business, which informs

Thus to mine eyes."

(Shakespeare, 1994: s. 44-45).

Bu söylemdeki "I have thee not, and yet I see thee still" (Shakespeare, 1994: s. 44) ["Yoksun elimde; ama görüyorum seni" (Shakespeare, 2017: s. 29)] cümlesi, "A dagger of the mind, a false creation / Proceeding from the heat-oppressed brain?" (Shakespeare, 1994: s. 45) ["Kafamdaki bir hançer misin yoksa? / Ateşli beynim mi yarattı seni?" (Shakespeare, 2017: s. 29)] cümlesi ve "Mine eyes are made the fools o' th' other senses, / Or else worth all the rest" (Shakespeare, 1994: s. 45) ["Ya gözlerim öbür duyularımla oynuyor" (Shakespeare, 2017: s. 29)/ Ya da gözlerim öbür duyularımın hepsine değer5]

5 Tarafımızdan çevrilmiştir. 
cümlesi Macbeth’in Duncan’ı öldürmeden önceki söylemidir. Kral Duncan’ı öldüreceği için içinde bulunduğu korku ve tereddüt tutkuları sebebiyle söyleyen Macbeth bu söylemde kavramlaştırıcı bileşenin etkisiyle değil, tutku kökenli içkin bileşenin etkisiyle bu söylemi üretmektedir. Öztürk Kasar'ın (2017) yükümsüz özneler sınıflandırmasına göre söyleyen bu söylemde esenliksiz durumda tutkular türündeki içkin bileşenden kaynaklanan bedensel dengesizlik durumunda yükümsüz özneye dönüşmüştür. Yükümsüz özne saptanan bu söylemin Türkçe çevirileri aşağıdadır.

EM1

\section{"MACBETH}

Şu önümde gördüğün bir hançer mi? Kabzası da elime doğru çevrilmiş. Gel, yakalıyayım seni. Ele geçmiyorsun, ama seni hala görüyorum. Meşum hayal, göze görülür de elle tutulmaz mısın? Yoksa, sadece zihnin yarattığı bir hançer misin, ateş içinde yanan kafanın uydurduğu bir hayal misin? Seni hala görüyorum, tutulacak gibisin, tıpkı şu kınından sıyırdığım hançer gibi. Bana tuttuğum yolu gösteriyorsun, kullanacağım aletin de işini. Gözlerim ya bütün öbür hislerimin eğlencesi oldu, yahut değerce hepsine bedel. Seni hala görüyorum. Hem yüzünde, hem sapında kan damlaları var; demin yoktu. Öyle hançer filan yok. Gözlerime böyle tesir eden o kanlı iştir.”

(Shakespeare, 1946: s. 28-29).

EM2

\section{"MACBETH}

Bir hançer mi önümde gördüğüm?

Sapı elimden yana çevrik...

Gel, sarsin elim seni.

Uğursuz görüntü, göze var ele yok musun sen?

Kafamdaki bir hançer misin yoksa?

Ateşli beynim mi yarattı seni?

Görüyorum işte yine; tutulacak gibisin,

Şu kınından çıkardığım hançer gibi.

Gideceğim yeri gösteriyorsun bana

Ve kullanacağım silahın ta kendisini.

Ya gözlerim öbür duyularımla oynuyor,

Ya öbür duyularım gözlerimle.

Yine görüyorum işte seni:

Ağzında ve sapında kan var; demin yoktu.

Yok, hançer falan yok.

Benim kanlı tasarım bu gözlerimin gördüğü."

(Shakespeare, 1967: s. 40).

EM3

\section{"MACBETH}

Bu ne? Bir hançer mi önümde beliren,

Kabzası elime yakın? Gel hadi, gir elime!

Tutamıyorum seni, ama hala görüyorum.

Ey ölümcül hayal, göze görünüyorsun, 
Subjectivity: a step of semiotics of translation and translation evaluation of a play from semiotics of translation point of view / M. Kuleli (p. 33-72)

Ama ele gelmiyorsun, öyle mi?

Yoksa kafamın içinde misin yalnızca?

Sahte bir hançer! Hummalı beynimin ürünü!

İşte hala ordasın; çektiğim şu hançer kadar gerçek.

Demek bana yol gösteriyorsun;

Böyle bir alet vardı benim aklımda da!

Ya gözlerim öteki duyularımın maskarası oldu;

Ya da o ikisi, ötekilerin hepsine bedel.

Hep gözümün önündesin; üstelik şimdi,

Hem ağzında hem kabzanda kan pıhtısı var.

Daha önce bunlar yoktu üstünde.

Hayır, olamaz böyle şey. Hayal görüyorum;

Kafamdaki şu kanlı iş yüzünden.”

(Shakespeare, 2000: s. 49).

\section{$\mathrm{EM}_{4}$}

\section{"MACBETH}

Şu önümde gördüğüm bir hançer mi?

Kabzası elime doğru çevrili,

Gel, tutayım seni!

Yoksun elimde, oysa görüyorum seni.

Kaderin dayattığı görüntü,

Göze görünür, ele gelmez misin sen?

Zihnin yarattı̆̆ı bir hançer,

Ateşler içinde yanan beynimin uydurduğu

Bir hayal misin yoksa?

Hala görüyorum, seni tutacağım sanki

Tıpkı şu kınından sıyırdı̆̆ım hançer gibi.

Gideceğim yeri gösteriyorsun bana

Ve kullanacağım silahın bir eşini.

Gözlerim ya oynuyor duyularımla

Ya da duyularım gözlerimle.

Yine görüyorum seni işte;

Bıçağında ve sapında kan var şimdi,

Demin yoktu oysa.

Hayır, hançer falan yok.

Gördüğümü sandığım benim kanlı planım.”

(Shakespeare, 2015: s. 46-47).

“Mine eyes are made the fools o' th' other senses, / Or else worth all the rest" (Shakespeare, 1994: s. 45) söylemi EM1'de "Gözlerim ya bütün öbür hislerimin eğlencesi oldu, yahut değerce hepsine bedel" 
(Shakespeare, 1946, s. 29); EM3’te "Ya gözlerim öteki duyularımın maskarası oldu / Ya da o ikisi, ötekilerin hepsine bedel” (Shakespeare, 2000: s. 49) olarak çevrilmiştir. Yükümsüz özne durumundaki söyleyen bu söyleme göre gördüğü şeyin gerçek olup olmadığının farkında bile değildir. Bu yüzden gözleri eğer doğru görüyorsa, duyma, tat alma, dokunma, koklama duyularının tümünün ancak gözleri kadar değerli olabileceğini düşünmektedir. EM2'de bu söylem "Ya gözlerim öbür duyularımla oynuyor, / Ya öbür duyularım gözlerimle” (Shakespeare, 1967: s. 40) olarak çevrilmiştir. Bu çeviride, özgün metindeki "worth all the rest" göstergesi diğer duyuların gözleri hataya düşürüyor olması olarak çevrilmiştir. Her ne kadar özgün metindeki söylemden bazı izler taşısa da, EM3’te bu söylemin çevirisinde yanlış bir anlam ortaya çıkmıştır ve bu durum Öztürk Kasar’ın (Öztürk Kasar ve Tuna, 2015) dizgeselliğine göre anlamın bozulması eğilimine örnek gösterilebilir. EM4’te ise bu söylem “Gözlerim ya oynuyor duyularımla / Ya da duyularım gözlerimle" (Shakespeare, 2015: s. 47) olarak çevrilmiştir. EM2'de olduğu gibi EM4'te de bu söylemin çevirisinde “worth all the rest” göstergesiyle tamamiyla ilintisiz olmamakla beraber yanlış bir anlam ortaya çıkmıştır ve Öztürk Kasar’ın (Öztürk Kasar ve Tuna, 2015) dizgeselliğine göre anlamın bozulması eğilimi olduğu düşünülebilir.

Yükümsüz Özne Söylemi 3:

\section{"MACBETH}

Methought I heard a voice cry, Sleep no more:

Macbeth does murder Sleep,

....

Still it cri'd, Sleep no more to all the House:

Glamis hath murther'd Sleep, and therefore Cawdor

Shall sleep no more: Macbeth shall sleep no more.

\section{LADY MACBETH}

Who was it, that thus cried? Why worthy Thane,

You do unbend your noble strength, to think

So brain-sickly of things."

(Shakespeare, 1994: s. 47).

Özgün metindeki "Methought I heard a voice cry, Sleep no more: / Macbeth does murder Sleep" (Shakespeare, 1994: s. 47) ["Bir ses duyar gibi oldum: / 'Kimseler uyumasın artık! Macbeth uykuyu öldürdü!'” (Shakespeare, 2017: s. 32)] Macbeth'in Kral Duncan’ı öldürdükten sonra kavramlaştırıcı bileşenin etkisini yitirdiği esnada ürettiği bir söylemdir. Bu söylemde söyleyenin kavramlaştırıcı bileşenin etkisinden çıktığı, özne konumunda bulunan Lady Macbeth'in "Who was it, that cried? Why worthy Thane, / You do unbend your noble strength, to think / So brain-sickly of things" (Shakespeare, 1994: s. 47) ["Kimmiş bu bağıran? Ah koca Macbeth, / Soylu gücünü yıpratıyorsun bu bozuk düşüncelerle" (Shakespeare, 2017: s. 33)] söylemiyle doğrulanmaktadır. Macbeth bu söylemi üretirken diğer soyluların Duncan'ı onun öldürdüğünü anlayacağından kaynaklanan korku ve ona her zaman güvenen bir kralı öldürdüğü için üzüntü gibi tutku kökenli içkin bileşenin etkisi altındadır. Öztürk Kasar’ın (2017) yükümsüz özneler sinıflandırmasına göre söyleyen bu söylemde esenliksiz durumda tutkular türündeki içkin bileşenden kaynaklanan bedensel dengesizlik durumunda yükümsüz özneye dönüşmüştür. Yükümsüz özne saptanan bu söylemin Türkçe çevirileri aşağıdadır. 
Subjectivity: a step of semiotics of translation and translation evaluation of a play from semiotics of translation point of view / M. Kuleli (p. 33-72)

\section{EM1}

\section{"MACBETH}

Bana öyle geldi ki bir ses ‘Artık uyumayın, Macbeth uykuyu öldürüyor!’ diye bağırdı....Ses uyuyanların hepsine, durmadan 'Uyumayın!' diye bağırıyordu, 'Glamis uykuyu öldürdü, onun için Cawdor bir daha uyumiyacak!”

\section{LADY MACBETH}

Böyle bağıran kimdi? Değerli efendimiz, bu sakat düşüncelerle asil kudretinizi zayıf düşürüyorsunuz."

(Shakespeare, 1946: s. 31-32).

\section{EM2}

\section{“MACBETH}

Bir ses duyar gibi oldum:

'Kimseler uyumasın artık! Macbeth uykuyu öldürdü!'

Yeniden yükseldi ses: uyumayın artık:

Glamis uykuyu öldürdü. Onun için

Cawdor'a uyku yok artık! Macbeth'e uyku yok artık.

\section{LADY MACBETH}

Kimmiş bu bağıran? Ah koca Macbeth

Soylu gücünü yıpratıyorsun bu bozuk düşüncelerle.”

(Shakespeare, 1967: s. 44).

\section{EM3}

\section{"MACBETH}

Sanki bir ses duymuşum gibi geldi;

'Uyku yok artık!' diye bağırıyordu,

'Macbeth uykuyu katletti!'

Ses, şatonun her yerinde çın çın ötüyordu,

'Uyku yok artık!' diye, Glamis uykuyu katletti,

Onun için Cawdor'a da uyku yok artık;

Macbeth'e uyku yok artık.

\section{LADY MACBETH}

Kimmiş böyle bağıran? Bu ne hal Lordum?

Böyle meczup gibi aklını takarsan bu işlere,

O yaman iradenden eser kalmaz yakında.”

(Shakespeare, 2000: s. 53-54).

$\mathrm{EM}_{4}$

\section{"MACBETH}

Feryat eden bir ses duyar gibi oldum: 
'Kimse uyumasin artık!

Macbeth uykuyu öldürdü!'

…

O ses durmadan haykırıyordu evdekilerin hepsine:

'Uyumayın bundan böyle;

Glamis uykuyu öldürdü,

Bu yüzden Cawdor uyumayacak!

Macbeth'e uyku yok artık!' diye.

\section{LADY MACBETH}

Kimmiş böyle seslenen? Ah, yüce Efendim,

Soylu gücünüzü tüketiyorsunuz böyle sakat düşüncelerle.”

(Shakespeare, 2015: s. 50).

Özgün metindeki "Macbeth shall sleep no more" cümlesi EM2'de "Macbeth'e uyku yok artık" (Shakespeare, 1967: s. 44); EM3’te "Macbeth'e uyku yok artık" (Shakespeare, 2000: s. 53); EM4'te “Macbeth'e uyku yok artık” (Shakespeare, 2015: s. 50) olarak Türkçeye çevrilmiştir. Ancak EM1'de bu cümle tamamen silinmiştir ve çevrilmemiştir. Bu durum, Öztürk Kasar'ın (Öztürk Kasar ve Tuna, 2015) dizgeselliğine göre anlamın yok edilmesi olarak düşünülebilir.

Yükümsüz Özne Söylemi 4:

\section{"MACDUFF}

O horror, horror, horror,

Tongue nor heart cannot conceive, nor name thee.

\section{MACBETH and LENNOX}

What's the matter?

\section{MACDUFF}

Confusion now hath made his masterpiece:

Most sacrilegious murder hath broke ope

The Lord's anointed Temple, and stole thence

The life o' th' building.

\section{MACBETH}

What is 't you say? the life?

LENNOX

Mean you his majesty?

\section{MACDUFF}

Approach the chamber, and destroy your sight

With a new Gorgon. Do not bid me speak:

See, and then speak yourselves:"

(Shakespeare, 1994: s. 51).

Bir önceki söylemde Duncan’ı öldüren Macbeth, Lady Macbeth’in yanına gittiğinde yükümsüz özne olarak söylem üretmişti. Bu söylemde ise sabah Duncan'ı ziyarete gelen soylular Duncan'ın öldüğünü 
Subjectivity: a step of semiotics of translation and translation evaluation of a play from semiotics of translation point of view / M. Kuleli (p. 33-72)

görürler ve Macbeth özne konumuna dönmüştür, kavramlaştırıı bileşenin etkisi altında tasarladıkları plana göre adım atmaktadır ve "What is' t you say? The life?" (Shakespeare, 1994: s. 51) [“Neler söylüyorsun, ne canı" (Shakespeare, 2017: s. 37)] söylemiyle bu cinayetten habersiz gibi davranmaktadır. Dolayısıyla geceden sabaha kadar kavramlaştırıcı bileşeni geri kazanmıştır ve özne konumuna dönüşmüştür. Ancak İskoçya soylularından Macduff, Duncan’ın öldüğünü görünce “O horror, horror, horror, / Tongue nor heart cannot conceive, nor name thee” (Shakespeare, 1994: s. 51) ["Korkunç! Korkunç!.. Korkunç felaket! / Diller anlatamaz seni! Yürekler dayanamaz sana!" (Shakespeare, 2017: s. 37)] cümlelerinden anlaşılabileceği üzere kavramlaştıııcı bileşenin etkisinden çıkar ve yaşadığı büyük üzüntü, tutku kökenli içkin bileşenin etkisinin altında bu söylemi üretmiştir. Öztürk Kasar'ın (2017) yükümsüz özneler sınıflandırmasına göre söyleyen bu söylemde esenliksiz durumda tutkular türündeki içkin bileşenden kaynaklanan bedensel dengesizlik durumunda yükümsüz özneye dönüşmüştür. Yükümsüz özne saptanan bu söylemin Türkçe çevirileri aşağıdadır.

EM1

"MACDUFF

Ah, felaket felaket! Seni hatırlamaya da anmıya da ne dil razı olur, ne gönül!

MACBETH - LENOX

Ne oldu ki?

MACDUFF

Düzeni altüst olan işlerin şahseseri bu! Çok kafirce bir cinayet. Tanrının mukaddes mabedine zorla girerek oradan yapının canını almış!

\section{MACBETH}

Ne dediniz? Canını mı?

\section{LENOX}

Hükümdarımızın mı demek istiyorsunuz?

\section{MACDUFF}

Oraya gidin de gözlerinizi yeni bir Gorgon kör etsin. Benden söz beklemeyin. Görün de söyleneceği kendiniz söylersiniz."

(Shakespeare, 1946: s. 36-37).

EM2

\section{"MACDUFF}

Korkunç! Korkunç!.. Korkunç felaket!

Diller anlatamaz seni! Yürekler dayanamaz sana!

\section{MACBETH VE LENNOX}

$\mathrm{Ne}$ var? Ne oldu?

\section{MACDUFF}

Böylesine canavarlık görülmemiş.

Cinayetlerin en cehennemliği

Tanrının evini talan etmiş de sanki

Tapılan canı almış içinden...

\section{MACBETH}

Neler söylüyorsun? Ne canı? 


\section{LENNOX}

Krala mı bir şey oldu?

MACDUFF

Gidin odaya da taş kesilsin gözleriniz.

Yılan saçlı Gorgon'u görmüş gibi.

Beni konuşturmayın; gidin görün,

Sonra kendiniz konuşun konuşabilirseniz.”

(Shakespeare, 1967: s. 50-51).

EM3

"MACDUFF

Ah, korkunç! Korkunç! Korkunç!

Söz yetmez anlatmaya,

İnsan aklı kavramayaz!

\section{MACBETH VE LENNOX}

Ne var, ne oldu?

\section{MACDUFF}

Felaket! En kötü şey oldu! İmansız caniler,

Tanrı'nın kutsal mabedine zorbaca girip,

İçindeki canı çalmışlar.

\section{MACBETH}

Ne demek istiyorsun? Hangi canı?

\section{LENNOX}

Majeste mi yoksa?

\section{MACDUFF}

Odaya gelin de, Gorgon'u görmüş gibi

Kör olup taş kesilin siz de.

Kendi gözlerinizle görün ve ona göre konuşun.”

(Shakespeare, 2000: s. 58-59).

\section{$\mathrm{EM}_{4}$}

\section{"MACDUFF}

Ah, korkunç, korkunç, dehşet verici bir felaket!

Diller anlatamaz, yürekler dayanamaz buna!

\section{MACBETH VE LENNOX}

Ne var? Ne oldu?

MACDUFF

Felaketin yıkımı başyapıtını yarattı şimdi!

Kutsallığa saygısızlık edilmiş bir cinayet bu,

Tanrının kutsal tapınağı yağmalanmış 
Subjectivity: a step of semiotics of translation and translation evaluation of a play from semiotics of translation point of view / M. Kuleli (p. 33-72)

Tapınağın canı oradan çalınmış.

MACBETH

Neler söylüyorsunuz? Ne canı?

LENNOX

Kral'dan mı söz ediyorsunuz?

MACDUFF

Odasına gidin de taş kesilsin gözleriniz,

Yeni bir Gorgon görmüşsünüz gibi.

Beni konuşturmaynn; kendi gözlerinizle görün

O zaman konuşun, konuşabilirseniz eğer."

(Shakespeare, 2015: s. 54-55).

Özgün metindeki "Confusion now hath made his masterpiece" cümlesi EM1'de "Düzeni altüst olan işleri şaheseri bu" (Shakespeare, 1946: s. 36); EM4'te "Felaketin yıkımı başyapıtını yarattı şimdi” (Shakespeare, 2015: s. 55) cümleleriyle Türkçeye aktarılmıştır ve herhangi bir anlam bozucu eğilim saptanmamıştır. Ancak EM2'de bu cümle "Böylesine canavarlık görülmemiş" (Shakespeare, 1967: s. 50) olarak çevrilmiş ve özgün metindeki göstergeler ile neredeyse tamamen ilintisiz göstergeler kullanılarak aykırı anlam ortaya çımıştır. Bu durum, Öztürk Kasar’ın (Öztürk Kasar ve Tuna, 2015) dizgeselliğine göre analmın saptırılması eğilimine örnek gösterilebilir. EM3’te de "Felaket! En kötü şey oldu" (Shakespeare, 2000:s. 59) olarak çevrilmiş ve özgün metindeki anlamla neredeyse ilintisiz bir anlam üretilerek Öztürk Kasar’ın (Öztürk Kasar ve Tuna, 2015) dizgeselliğine göre anlamın saptırılması eğilimi saptanmıştır. Ayrıca bu söylemde "Gorgon" göstergesi ile metinlerarası bir ilişki kurulmuştur. Bu gösterge EM1, EM3 ve EM4te "Gorgon” göstergesi ile karşlanmış ve metinlerarasıllı ilişkisi devam ettirilmiştir. Ancak EM2'de "yılan saçlı Gorgon” (Shakespeare, 1967: s. 51) göstergesi kullanılmıştır ve özgün metinde yer almayan "yllan saçlı" nitelemesi, "Gorgonların yılan saçlı olarak portrelenmesi" (Hansen ve Hansen, 2005: s. 158) sebebiyle EM2'de çevirmen tarafından aşırı yorum katılarak Türkçeye çevrilmiştir. Bu durum, Öztürk Kasar'ın (Öztürk Kasar ve Tuna, 2015) dizgeselliğine göre anlamın aşırı yorumlanması eğilimi olarak görülebilir. Özgün metinde yer alan “Do not bid me speak” cümlesi EM1'de "Benden söz beklemeyin" (Shakespeare, 1946: s. 37); EM2'de "beni konuşturmayın" (Shakespeare, 1967: s. 51); EM4'te "Beni konuşturmayın” (Shakespeare, 2015: s. 55) olarak çevrilirken, EM3’te bu cümle çevrilmemiştir ve yükümsüz özne olan olan söyleyenin üzüntüden dolayı konuşmak istememesi çeviri metin okuruna aktarılmamıştır. Özgün metinde yükümsüz özne söylemi için anlam taşıyan bir birimin EM3’te silinmesi, Öztürk Kasar’n (Öztürk Kasar ve Tuna, 2015) dizgeselliğine göre anlamın yok edilmesi olarak düşünülebilir.

Yükümsüz Özne Söylemi 5:

"BANQUO

O, treachery!

Fly good Fleance, fly, fly, fly.

Thou mayst revenge. O slave!"

(Shakespeare, 1994: s. 65).

Macbeth’in gönderdiği katiller Banquo ve oğlu Fleance’ı öldürmek için akşam karanlığında saldırıya geçtiklerinde Banquo ölmek üzereyken bu söylemi üretmiştir. Söylemdeki “fly” (kaç) göstergesi dört defa 
tekrarlanmıştır ve Banquo, oğlu Fleance’ın kaçması için kendini feda etmiştir. Banquo, oğlu Fleance’a kendini adamıştır ve onun hayatta kalması için ölümü bile göze almıştır. Kavramlaştırıcı bileşenin etkisinin yok olduğu bu söylemde söyleyen simgesel güçler kökenli aşkın bileşenin etkisi altındadır. Öztürk Kasar’n (2017) yükümsüz özneler sınıflandırmasına göre söyleyen bu söylemde bir işleve indirgenmiş bireysel biçim-özne olarak sınıflandırılabilir. Bu söylemin Türkçe çevirileri aşağıdadır:

EM1

"BANQUO

Ah, hıyanet! Kaç Fleance'cı̆̆ım, kaç, kaç, kaç! Belki intikam alırsın...Ah, alçak! (Ölür).”

(Shakespeare, 1946: s. 52-53).

EM2

"BANQUO

Ah, Kalleşler! Kaç Fleance’im, kaç! kaç! kaç!

Kaç da öcümü al! Ah, alçak! (Banquo vurulup ölür).”

(Shakespeare, 1967: s. 73).

EM3

"BANQUO

Ah! Hainler! Kaç Fleance, kaç evladım, kaç, kaç, kaç!

Öcümü al! Ah, alçaklar! (Banquo ölür).”

(Shakespeare, 2000: s. 79).

$\mathrm{EM}_{4}$

"BANQUO

Ah, sizi kalleşler! Kaç, Fleance, kaç,

Kaç da intikamımı al. Ah, alçaklar! (ölür).”

(Shakespeare, 2015: s. 72).

Özgün metindeki "Thou mayst revenge" (Shakespeare, 1994: s. 65) söylemi, EM2'de "öcümü al" (Shakespeare, 1967: s. 73); EM3’te “öcümü al” (Shakespeare, 2000: s. 79); EM4’te "intikamımı al" (Shakespeare, 2015: s. 72) olarak çevrilmiştir ve "mayst" kipinin dilek-şart kipi anlamı erek metinlerde yansitılmıştır. Ancak EM1'deki "Belki intikam alırsın" (Shakespeare, 1946: s. 53) söyleminde "mayst" kipi İngilizcedeki potansiyel diğer bir anlamı olan ihtimal anlamıla çevrilmiştir. EM1'deki yükümsüz özne söyleminin çevirisinde özgün metindeki bir göstergenin potansiyel ama özgün metin bağlamında gerçekleşmemiş olan bir anlamı kullanıldığı için, Öztürk Kasar’ın (Öztürk Kasar ve Tuna, 2015) dizgeselliğine göre bu durum anlamın kaydırılması olarak sınıflandırılabilir.

Yükümsüz Özne Söylemi 6:

\section{"MACBETH}

The table's full.

LENNOX

Here is a place reserv'd Sir. 
Subjectivity: a step of semiotics of translation and translation evaluation of a play from semiotics of translation point of view / M. Kuleli (p. 33-72)

\section{MACBETH}

Where?

LENNOX

Here my good lord.

What is't that moves your Highness?

\section{MACBETH}

Which of you have done this?

LORDS

What, my good lord?

\section{MACBETH}

Thou canst not say I did it: never shake

Thy gory locks at me.

ROSS

Gentlemen rise, his Highness is not well.

…

\section{LADY MACBETH}

O proper stuff:

This is the very painting of your fear:

This is the air-drawn dagger which you said

Led you to Duncan.”

(Shakespeare, 1994: s. 67-68).

Macbeth’in verdiği yemek şöleninde katillerin ona Banquo'nun öldürüldüğünü ancak oğlu Fleance’ın kaçtı̆̆ını haber etmesi üzerine Macbeth’in tüm neşesi kaçar ve cadıların ona kral olacağını müjdelediği zaman Banquo'ya da kral babası olacağını müjdelemeleri sebebiyle, hayatta olan Fleance'tan korkmaya başlar. Tüm bu korkular içinde şölende kendisi için ayrılan masada Banquo'nun hayaletini gören Macbeth, kavramlaştırıı bileşenin etkisinden çıkar ve tutkular türündeki içkin bileşenin güdümüne girerek bu söylemi yükümsüz özne olarak üretir. "Which of you have done this?” (Shakespeare, 1994: s. 67) [Hanginiz yaptınız bunu?6] cümlesi yemekteki davetlilere hitaben söylenmiştir ve söyleyen, Banquo'nun hayaletini kendi sandalyesine kimin koyduğunu davetlilere soracak kadar yargı kabiliyetini yitirmiştir ve yükümsüz özneye dönüşmüştür. Aynı zamanda, "Thou canst not say I did it: never shake / thy gory locks at me" (Shakespeare, 1994: s. 67) [Ben yaptım diyemezsin, kanlı perçemlerini sallama bana ${ }^{7}$ cümlesinde söyleyen sandalyesinde oturan hayalete hitap etmektedir. Tüm davetlilerin önünde, üstelik davetlilerin görmediğini bile anlamadığı bir hayaletle konuşması da söyleyenin içkin bileşenin güdümünde olduğunu doğrulamaktadır. Söyleyen, korku ve endişe gibi tutkulardan dolayı yargı kabiliyetini yitirmesi sebebiyle, bu söylemdeki söyleyen Öztürk Kasar’ın (2017) yükümsüz özneler sınıflandırmasına göre esenliksiz durumda tutkular türündeki içkin bileşenden kaynaklanan bedensel dengesizlik durumunda yükümsüz özneye dönüşmüştür. Yükümsüz özne saptanan bu söylemin Türkçe çevirileri aşă̆ıdadır. 
EM1

"MACBETH

Masa dolu.

LENOX

Burada bir yer ayrıldı, efendimiz.

MACBETH

Nerede?

LENOX

Burada, aziz efendimiz. Haşmetlimizi heyecanlandıran nedir?

MACBETH

Bunu hanginiz yaptınız?

BEYLER

Neyi efendimiz?

\section{MACBETH}

Benim yaptığımı söyliyemezsin: kanlı perçemlerini bana doğru sallama hiç.

ROSSE

Beyler, kalkın; haşmetlimiz iyi değiller.

\section{LADY MACBETH}

Haydi, laf! Bu senin korkundan doğan bir hayal: havada ilerliyerek seni Duncan’a doğru götürdüğünü söylediğin hançer."

(Shakespeare, 1946: s. 55-56).

EM2

"MACBETH

Sofrada yer yok.

LENNOX

Buyurun; işte, yeriniz hazır, kralım.

\section{MACBETH}

Nerede?

LENNOX

İşte, buyurun kralım. Neniz var, efendimiz?

MACBETH

Kim yaptı bunu?

BEYLER

Neyi, efendimiz?

MACBETH

Ben yaptım diyemezsin elbet!

Beni gösterme öyle, kanlı başını sallayıp.

ROSS

Baylar, kalkalım; Kralımız rahatsı. 
Subjectivity: a step of semiotics of translation and translation evaluation of a play from semiotics of translation point of view / M. Kuleli (p. 33-72)

\section{LADY MACBETH}

Bırak bu saçmaları!

Korkudan hayal görmeğe başladın yine:

O havada duran hançer gibi hani,

Sözde seni Duncan'a doğru süren hançer.”

(Shakespeare, 1967: s. 77-79).

EM3

"MACBETH

Ama masada yer yok.

LENNOX

Yeriniz burada efendim.

\section{MACBETH}

Nerede?

\section{LENNOX}

İşte burada, sayın Lordum. Ne oldu, canınızı sıkan bir şey mi var, ekselans?

MACBETH

Bunu hanginiz yaptı?

LORDLAR

Neyi, sayın Lordum?

MACBETH (Hayalete)

Sen yaptın diyemezsin bana! O kanlı saçlarını da bana doğru savurma öyle!

ROSS

Baylar, kalkın, ekselansları iyi değil.

....

\section{LADY MACBETH}

Hadi canım!

Hayali bir korku seninki.

Hani, havada asılı hançerden söz etmiştin ya,

'Beni Duncan'a götürdü’ dediğin hançer;

Bu da tıpkı onun gibi.”

(Shakespeare, 2000: s. 82-84).

$\mathrm{EM}_{4}$

"MACBETH

Sofrada yer yok ki.

LENNOX

Buyrun işte yeriniz hazır, efendimiz.

MACBETH 
Nerede?

LENNOX

Burada, yüce lordum.

Sizi bu kadar heyecanlandıran nedir, efendimiz?

MACBETH

Hanginiz yaptı bunu?

LORDLAR

Neyi, yüce lordum?

MACBETH

Ben yaptım diyemezsin elbette.

Kanlı perçemlerini sallayıp beni gösterme öyle.

ROSS

Beyler, kalkalım, Kralımız rahatsızlandı.

....

\section{LADY MACBETH}

Bırakın bu saçmalıkları!

Bu sizin korkunuzdan doğan bir hayal sadece.

Bu da, o havada duran hançer,

Hani sizi Duncan'a götüren hançer gibi.”

(Shakespeare, 2015: s. 75-76).

Özgün söylemdeki “This is the very painting of your fear" (Shakespeare, 1994: s. 68) cümlesi EM1'de "bu senin korkundan doğan bir hayal" (Shakespeare, 1946: s. 56); EM2'de "korkudan hayal görmeğe başladın yine" (Shakespeare, 1967: s. 78); EM4’te "sizin korkunuzdan doğan hayal sadece" (Shakespeare; 2015: s. 76) olarak çevrilmiştir ve özgün metindeki gibi söyleyenin yükümsüz özneye dönüşmesinin sebebi olarak korku kaynaklı bir tutku gösterilmiştir. EM3’te ise bu cümle "hayali bir korku seninki” (Shakespeare, 2000: s. 83) olarak çevrilmiştir ve yükümsüz özne konumunda olan söyleyenin hayal gördüğü çeviri metin okuruna aktarılmamış olmakla birlikte yükümsüz özneye dönüşmesinin sebebi korku olarak gösterilmemiştir. Her ne kadar özgün metindeki söylemden izler taşısa da, EM3’te yanlış bir anlam ortaya çıkmıştır ve bu durum Öztürk Kasar'ın (Öztürk Kasar ve Tuna, 2015) dizgseselliğine göre anlamın bozulması eğilimi olarak görülebilir.

Yükümsüz Özne Söylemi 7:

\section{"MACBETH}

Avaunt, and quit my sight, let the earth hide thee:

Thy bones are marrowless, thy blood is cold:

Thou hast no speculation in those eyes

Which thou dost glare with.

\section{LADY MACBETH}

Think of this good Peers

But as a thing of custom: 'tis no other,

Only it spoils the pleasure of the time. 
Subjectivity: a step of semiotics of translation and translation evaluation of a play from semiotics of translation point of view / M. Kuleli (p. 33-72)

\section{MACBETH}

What man dare, I dare:

Approach thou like the rugged Russian bear,

The arm'd rhinoceros, or th' Hyrcan tiger,

Take any shape but that, and my firm nerves

Shall never tremble. Or be alive again,

And dare me to the desert with thy sword:

If trembling I inhabit then, protest me

The baby of a girl. Hence horrible shadow,

Unreal mockery, hence!

Exit Ghost.

Why so, being gone,

I am a man again.”

(Shakespeare, 1994: s. 69-70).

Macbeth, bu söylemde "Exit Ghost” (hayalet çıar) bölümüne kadar davetlilerin önünde halen yemekte sandalyesine oturan Banquo’nun hayaletiyle konuşmaktadır. Lady Macbeth'in davetlilere "a thing of custom” söylemiyle bunun arada olan bir durum olduğunu söylemesine rağmen Macbeth, Lady Macbeth'in sözlerini duymayarak ve davetlilere hiç aldırmayarak hayalet ile konuşmaya devam etmektedir. Bir önce örnekteki korkudan dolayı kavramlaştırıcı bileşenin etkisini yitirmesi bu örnekteki söylemlerde de devam etmektedir ve korku kökenli tutkuların güdümünde olması, söyleyenin bu söylemi içkin bileşenin etkisi altında ürettiğini düşündürmektedir. Öztürk Kasar’ın (2017) yükümsüz özneler sınıflandırmasına göre söyleyen bu söylemde esenliksiz durumda tutkular türündeki içkin bileşenden kaynaklanan bedensel dengesizlik durumunda yükümsüz özneye dönüşmüştür. Söylemin sonuna doğru hayaletin çıkmasıyla söyleyen "being gone, I am a man again" (Shakespeare, 1994: s. 70) [Gitti ya, adam oldum yeniden ${ }^{8}$ ] cümlesiyle yine bir öznelik dönüşümü yaşayarak yükümsüz özneden yargı durumundaki ve kavramlaştırıcı bileşenin etkisi altındaki özne durumuna dönmüştür. Bu durum, korku kökenli bir tutkunun var olduğu durumlarda söyleyenin yargı yeteneğini kaybettiğini, ancak korkuyu doğuran durumun ortadan kalktığında yine özne durumuna dönebildiğini göstermektedir. Bu söylemin çevirileri aşağıdadır.

EM1

"MACBETH

Git oradan! Gözümün önünden çekil! Toprak seni gizlesin! Kemiklerinde ilik kalmadı, kanın dondu; dikip baktığın o gözlerde idrak diye bir şey yok ki!

\section{LADY MACBETH}

Beyler, bunu sadece yer etmiş bir adet bilin, fazla bir şey değil. Yalnız, toplantının neşesini kaçırıyor.

\section{MACBETH}

Bir adam neyi göze alırsa alırım: kıllı Rus ayısı gibi, dişli gergedan gibi, yahut Curcan illerinin kaplanı gibi gel; o şekle girme de hangi şekle girersen gir, sağlam sinirlerim bir kere bile titremez; yahut tekrar diril, kılıcını çekerek meydan oku, beni çöle çağır; o zaman da titrer kalırsam beni kız bebek ilan et. Haydi git, korkunç gölge! Asılsız alay, git!.

(Hayalet kaybolur.)

Tarafımızdan çevrilmiştir. 
Ya işte: o gitti, erkekliğim tekrar geldi.”

(Shakespeare, 1946: s. 57-58).

$\mathrm{EM} 2$

"MACBETH

Çekil! Git karşımdan! Git, toprak gizlesin seni!

Kanın kurudu senin; ilik yok artık kemiklerinde.

Bakış yok üstümüze diktiğin o gözlerde.

\section{LADY MACBETH}

Aldırmayın, beyler, olağan bir şey sayın bunu.

Bir şey değil aslında;

Keyfimizi bozuyor yalnız, o kadar.

\section{MACBETH}

Bir insan neyi göze alabilirse almışım göze.

Gel, yaklaş, kudurmuş Rus ayısı!

Azılı gergedan, cana susamış kaplan!

Böyle görünme de ne olursan ol:

Kılım kıpırdamayacak karşında.

Diril istersen, kılıcını çek, çağır beni

Issız bir yere. Korkar da evime kapanırsam,

Bir kızın bebeği de bana, bebeği de!

Çekil git, pis hortlak. Uydurma surat, çekil git!

(Hortlak çıkar.)

Bakın, o gitti, ben de adama döndüm yeniden!"

(Shakespeare, 1967: s. 80-81).

\section{$\mathrm{EM}_{3}$}

"MACBETH (Hayaleti görür.)

Defol! Gözüme görünme! Toprağın altına dön!

Kemiklerin iliksiz, kanın soğuk senin.

$\mathrm{O}$ ters ters bakan gözlerin göremez asla!

\section{LADY MACBETH}

Merak etmeyin, değerli Lordlar,

Bu zaman zaman oluyor. Önemli değil,

Ama yazık ki tadımızı kaçırıyor.

\section{MACBETH}

Erkek olmaya ben de erkeğim!

Azgın Rus ayısı gelsin isterse üstüme

Ya da zırhlı gergedan, veya Hyrcania kaplanı;

Seninki dışında, hangi kılıkta gelirse gelsin, 
Subjectivity: a step of semiotics of translation and translation evaluation of a play from semiotics of translation point of view / M. Kuleli (p. 33-72)

Hiç tınmam bile. Ya da, yine canlan da gel;

Al kılıcını istediğin kuytuda kapışalım.

O zaman da titrer, çıkamazsam karşına,

Ufacık, kız bebekten daha korkak de bana.

Yok ol karşımdan, korkunç gölge!

Gerçek dışı maskara, defol!

(Hayalet çıkar.)

İşte bakın, o gitti, ben yine erkek oldum.”

(Shakespeare, 2000: s. 85-86).

EM4

"MACBETH

Çekil! Git karşımdan! Toprak gizlesin seni!

İlik kalmadı artık kemiklerinde, kanın çoktan dondu;

Anlayış yok bana dikip baktığın o gözlerinde.

\section{LADY MACBETH}

Aldırmayın sayın Lordlar; olağan bir şey sayın bunu da.

Bir şey değil aslında;

Soframızın keyfini bozuyor yalnızca.

\section{MACBETH}

Bir insan neyi göze alabilirse, ben de almışım göze,

Gel, yaklaş bana, ister öfkeli Rus ayısı gibi,

İster zırhlı gergedan, ister Hazer kaplanı ol;

$\mathrm{Bu}$ şekle girme de, hangi şekilde gelirsen gel,

O zaman kılım kıpırdamaz karşında.

Ya da hayata dön, kılıcını çekip çağır beni,

Karşılaşalım ıssız bir yerde.

Korkar da kapanırsam evime

Hanım evladı diye alay et benimle.

Çekil git korkunç hayalet!

Gerçek olmayan hayal, defol!

(Hayalet kaybolur)

İşte gitti! Ben de kendime döndüm yeniden”

(Shakespeare, 2015: s. 78).

Özgün metinde Macbeth’in hayalete hitap ederek ürettiği "let the earth hide thee" (Shakespeare, 1994: s. 69) cümlesi EM1'de "Toprak seni gizlesin” (Shakespeare, 1946: s. 57); EM2'de Toprak gizlesin seni” (Shakespeare, 1967: s. 80); EM4’te "Toprak gizlesin seni” (Shakespeare, 2015: s. 78) cümleleriyle Türkçeye çevrilmiştir ve hayaletin toprak altında kalarak Macbeth'in gözüne görünür hale gelmemesi için toprağın bu hayaleti saklaması isteği çeviri metin okuruna da özgün metin okuruna olduğu gibi yansıtılmıştır. Ancak EM3’te bu cümle “Toprağın altına dön” (Shakespeare, 2000: s. 85) olarak çevrilmiştir ve söyleyenin bu hayaletin zaten toprak altında olduğunu bildiğini, yeniden oraya dönmesi 
için ona bir emir verdiğini düşündürmektedir. Bu durumda, söyleyen kavramlaştırıcı bileşenin etkisinden tam olarak çıkamamış olarak yorumlanabilir ve yükümsüz özne söylemi çeviri metin okuru için tam anlamıyla bir yükümsüz özne olarak alımlanamayabilir. EM3’teki bu çevirideki anlam bozucu eğilim Öztürk Kasar'ın (Öztürk Kasar ve Tuna, 2015) dizgeselliğine göre özgün metinle tamamen ilintisiz olmamakla birlikte ortaya yanlış anlam çıkması sebebiyle anlamın bozulması eğilimi olarak düşünülebilir.

Bu söylemdeki dikkat çeken diğer bir gösterge ise "Hyrcan tiger" göstergesidir. Hyrcania olarak da bilinen bu yer İran'da Hazar Denizi'ne yakın bir konumdadır. Bu söylemde bu gösterge metinlerarası bir ilişki yaratmıştır. Özgün metin okuru, bu göstergeyi çözümlemek için geri okumalarından veya yeni okumalardan yararlanmak zorunda kalacaktır. Aynı edebi hazzı alabilmek için erek metin okuruna da bu metinlerarasılık ilişkisinin yansıtılması beklenebilir.EMı'de bu gösterge "Curcan illerinin kaplanı" olarak çevrilmiştir. Curcan bugünkü İran'da bulunan bir kenttir. Her ne kadar Türkçe fonotaktiğine yaklaştırılmış olsa da ve metinlerarasılık ilişkisi korunmuş olsa da, özgün metindeki Hyrcan bir kaplan türü mü yoksa bir yer ismi mi bilinmezken EM1'de "iller" göstergesi ile buranın bir yer olduğu çevirmenin kendi yorumu ile okura açıcça belirtilmiştir. EM1'deki bu durum Öztürk Kasar'ın (Öztürk Kasar ve Tuna, 2015) dizgeselliğine göre anlamın aşırı yorumlanması eğilimi olarak düşünülebilir. EM2'de ise bu gösterge "cana susamış kaplan" olarak çevrilmiştir ve çevirmenin aşırı yorumuyla metinlerarasılık ilişkisi yok edilmiştir. Çevirmenin kendi yorumunu katmasıyla ortaya aşırı çevirinin çıkması, Öztürk Kasar’ın (Öztürk Kasar ve Tuna, 2015) dizgeselliğine göre anlamın aşırı yorumlanması olarak sınıflandırılabilir. EM4’te bu gösterge "Hazer kaplanı” olarak karşımıza çıkmaktadır. EMı'deki gibi Türkçe fonotaktiğine uydurulup metinlerarası ilişki korunmuştur ve Hazar Denizi’ne yakın bir konumda olan "Hazer", özgün metindeki anlama yakın bir konumdan bahsetmektedir. Bu göstergenin EM4’teki çevirisinde herhangi bir anlam bozucu eğilim saptanmamıştır. EM3’te ise bu gösterge "Hyrcania kaplanı" olarak çevrilmiş ve metinlerarasılık ilişkisi korunmuştur.

Bu söylemin çeviri değerlendirmesinde son olarak "the desert" göstergesi çözümlenmiştir. EM1'de bu gösterge "çöl” olarak çevrilirken; EM2'de "Issız bir yer”; EM3’te "kuytu”; EM4'te ise "issız bir yer" göstergeleriyle çevrilmiştir. Söylemin bağlamında ve hatta bu söyleme kadar oyunda hiç bir söylemde "çöl” göstergesi geçmezken, bu söylemde "desert" göstergesinin önüne İngilizcedeki belirtme artikeli olan "the" kullanılmıştır. Ancak bu söylemde veya daha önceki söylemlerde de açıklanan veya bahsedilen bir çöl söz konusu olmadığı için, bağlamın anlam evrenine "çöl” göstergesi uygun düşmemektedir. EM2, EM3 ve EM4’te kullanılan karşllıklar “the desert” göstergesi için uygun görülebiliyorken, EM1'deki “çöl” göstergesi “desert” göstergesinin potansiyel ancak özgün metinde gerçekleşmeyen bir anlamı olduğu için ortaya çıkan başka anlam Öztürk Kasar’ın (Öztürk Kasar ve Tuna, 2015) dizgeselliğine göre anlamın kaydırılması eğilimi olarak sınıflandırılabilir.

Yükümsüz Özne Söylemi 8:

\section{"DOCTOR}

I have two nights watch'd with you, but can perceive no truth in your report. When was it she last walk'd?

\section{GENTLEWOMAN}

Since his Majesty went into the field, I have seen her rise from her bed, throw her night-gown upon her, unlock her closet, take forth paper, fold it, write upon't, read it, afterwards seal it, and again return to bed; yet all this while in a most fast sleep.

DOCTOR 
Subjectivity: a step of semiotics of translation and translation evaluation of a play from semiotics of translation point of view / M. Kuleli (p. 33-72)

A great perturbation in nature, to receive at once the benefit of sleep, and do the effects of watching. In this slumbery agitation, besides her walking, and other actual performances, what (at any time) have you heard her say?"

(Shakespeare, 1994: s. 93)

Bu söylem, geceleri uyurken odasında uyurgezer durumda dolaşan ve konuşan Lady Macbeth'e çağrılan doktor ile Lady Macbeth'in yardımcısı arasında geçmektedir. Gece Lady Macbeth'in semptomlarını gözlemlemek için gelen doktora Lady Macbeth’in yardımcısı "I have seen her rise from her bed, throw her night-gown upon her, unlock her closet, take forth paper, fold it, write upon't, read it, afterwards seal it... all this while in a most fast sleep" (Shakespeare, 1994: s. 93) [Yatağından kalktığını, üstüne geceliğini aldığını, dolabını açtığını, bir kağıt alıp katladığını, üstüne bir şeyler yazıp okuduğunu, sonrasında mühürlediğini gördüm... tüm bunlar derin bir uyku halindeydi9] söylemini üretmiştir. Doktor ve Lady Macbeth’in yardımcısı bu söylemde kavramlaştırıcı bileşenin etkisinde özne konumunda iken, bir sonraki örnekte söylemleri çözümlenecek olan Lady Macbeth uyurgezer bir hasta durumundadır. Uyurgezer durumdaki tüm söylemleri kavramlaştırıcı bileşenden, dolayısıyla yargı yeteneğinden uzak olan Lady Macbeth, Öztürk Kasar’ın (2017) yükümsüz özneler sınıflandırmasına göre patolojik bir durumdan kaynaklanan bilinç eksikliği konumunda yükümsüz özneye dönüşmüştür. Bu söyleme göre Lady Macbeth, uyurgezer durumdayken temel bileşenin bile kısmen güdümünden uzaktadır çünkü etrafında konuşulanları bile duyamayacak kadar serin bir uyku halindedir. Ancak yazabildiğine göre ve dolabı açabildiğine göre görme ve dokunma duyuları halen uyarıcı alabiliyorken, bu yükümsüz özne durumu Macbeth’in korkularının onu da sardığından kaynaklanmış olabilir ve içkin bileşenin güdümünde bir uyurgezer olabilir. Bu söylemin çevirileri aşağıdadır.

EM1

\section{"HEKIM}

Sizinle iki gecedir bekliyorum ama dediklerinizi doğru çıkaracak bir şey göremedim. Son defa ne zaman yürüdü?

\section{NEDIME}

Haşmetlimiz sefere gittiğginden beri kaç defa yatağından kalktığını, üstüne geceliğini aldığını, çekmecesini açtığını, kă̆ıt çıkarıp katlayıp üstüne bir şey yazdığını, okuduğunu sonra mühürleyip tekrar yatağına döndüğünü gördüm. Hem de bütün bunları derin bir uykudayken yapıyordu.

\section{HEKIM}

Hem uykunun nimetinden faydalanmak, hem de uyanıklık eserlerini göstermek tabiatta büyük bir sarsıntı var demektir. Bu uykulu rahatsızlık içinde, yürümek ve öbür hareketleri yapmaktan başka, bir şey dediğini hiç işittiniz mi?”

(Shakespeare, 1946: s. 85).

\section{EM2}

\section{"HEKIM}

İki gecedir bekliyorum sizinle,

Hiç bir şey göremedim dediklerinize benzer.

En son ne zaman gördünüz

Kıraliçenin gece kalkıp gezdiğini

KADIN

Kıralımızın sefere çıktığı gece.

Tarafımızdan çevrilmiştir. 
Baktım yatağından kalktı, hırkasını giydi,

Çekmecesinden bir kağıt çıkarıp katladı,

Bir şeyler yazdı üstüne, mühürledi ve yattı:

Derin uykular içindeydi bütün bunları yaparken.

\section{HEKIM}

Büyük bir iç sarsıntısının belirtisi bu:

Uyku halindeki bünyede uyanıklık halleri

Bu uyur uyanıklık sirasinda

Yürümek ve daha başka haller dışında,

Ağzından bir şeyler duyduğunuz oldu mu?”

(Shakespeare, 1967: s. 118-119).

$\mathrm{EM}_{3}$

\section{"DOKTOR}

Seninle birlikte iki gece bekledim, ama dediğin gibi bir şey olmadı. Lady Macbeth en son ne zaman yürümüştü?

\section{NEDİME}

Majesteleri savaşa gittiğinden beri, geceleri yatağından kalkıyor, üstüne bir gecelik alıyor, dolabını açıyor, içinden bir kağıt çıkarıyor, katlıyor, üstüne bir șeyler yazıyor, okuyor, sonra yine mühürleyip yerine koyuyor ve yatağına dönüyor, ama bütün bunları hep derin uykuda yapıyor.

\section{DOKTOR}

Hiç doğal değil bu; hem uykunun etkisinde olmak, hem de uyanıkken yapılan şeyleri yapmak. Bu sıkıntılı uyku sırasında, yürüyüp dolaşması ve öteki hareketleri dışında, herhangi bir anda konuştuğu da oldu mu?"

(Shakespeare, 2000: s. 123).

\section{$\mathrm{EM}_{4}$}

\section{"HEKIM}

İki gecedir sizinle nöbetteyim. Ama dediklerinizi doğru çıkaracak bir şey göremedim. En son ne zaman yürüdü?

\section{NEDİME}

Kralımızın sefere çıktığı geceydi. Yatağından kalkıp üstüne şalını atıp çekmecesini açtı, bir kağıt çıarıp katladı, üstüne bir şeyler yazdı. Sonra okuyup mühürledi, kağıdı yerine koyup yatağına döndü; bütün bunları yaparken derin bir uykudaydı.

\section{HEKİ}

$\mathrm{Bu}$, büyük bir ruhsal sarsıntının belirtileri. Uyku durumundayken uyanıklık durumu! Yani bu uyur uyanıklık içinde yürümek ve diğer hareketlerde bulunmak. Peki, bir şeyler de söylüyor muydu?”

(Shakespeare, 2015: s. 109).

Özgün metindeki "When was it she last walk'd" (Shakespeare, 1994: s. 93) cümlesi EM1'de "Son defa ne zaman yürüdü (Shakespeare, 1946: s. 85); EM3’te "Lady Macbeth en son ne zaman yürümüştü" (Shakespeare, 2000: 123); EM4’te "En son ne zaman yürüdü” (Shakespeare, 2015: s. 109) cümleleriyle çevrilmiştir herhangi bir anlam bozucu eğilim saptanmamıştır. Ancak EM2'de bu cümle, "En son ne zaman gördünüz / Kıraliçenin gece kalkıp gezdiğini” (Shakespeare, 1967: s. 118) cümlesiyle çevrilmiştir. Özgün metinde Lady Macbeth’in uyurgezer olduğu okura, yardımcısının bir sonrakini söyleminde açlk 
Subjectivity: a step of semiotics of translation and translation evaluation of a play from semiotics of translation point of view / M. Kuleli (p. 33-72)

hale getirilmektedir ve bu söylemde doktorun cümlesinde sadece "walk'd" (yürüdüğünü) göstergesi bulunmaktadır. Doktor ilk söylemde uyurgezerliğe dair herhangi bir anlam birimi kullanmamıştır ve yazar, Lady Macbeth’in uyurgezer olduğunu okura bilinçli olarak bir sonraki söylemde aktarmak istemiş olabilir. Ancak EM2'de Lady Macbeth’in uyurgezer olduğu özgün metindekinden daha önceki bir söylemde erek metin okuruna açık hale getirilmiştir. Çevirmen, bu söylemde kendi yorumunu kullanmış ve aşırı çeviri ortaya çıkmıştır. Bu durumda, EM2'deki "gece kalkıp” göstergesi özgün metin bağlamında bulunmayan bir gösterge olduğu için Öztürk Kasar’ın (Öztürk Kasar ve Tuna, 2015) dizgeselliğine göre bu durum anlamın aşırı yorumlanması olarak sınıflandırılabilir.

Yardımcı kadının doktora cevap verdiği söylemde "Since his Majesty went into the field" (Shakespeare, 1994: s. 93) [Kralımız sefere gittiğinden beri ${ }^{10}$ ] cümlesi İngilizcedeki present perfect tense ile (I have seen) devam etmiştir. İngilizcede bu zaman, geçmişten günümüze devam etmek olan olayları veya çok kısa bir süre önce bitmiş olsa da etkisi devam eden olayları anlatmak için kullanılır. Bu bağlamda, bir durum yüklemi olan "see" (görmek) yüklemi kullanıldığından dolayı yüklem present perfect continuous tense ile kullanılamamıştır. Dolayısıyla, bu olay geçmişten bugüne devam eden olayları anlatmak için kullanılmıştır ve Lady Macbeth'e doktor getirilmiş olması bu durumun devam ettiğini göstermektedir. Present perfect tense ile kullanılan "since" bağlacı, Türkçedeki “-den beri” anlamını vermektedir. Bu yüzden, Macbeth sefere çıktığından beri Lady Macbeth'in geceleri uyurgezerlikten müzdarip olduğunun görüldüğü düşünülmelidir. EM1'de bu cümle "Haşmetlimiz sefere gittiğinde beri” (Shakespeare, 1946: s. 85); EM3'te “Majesteleri savaşa gittiğinden beri” (Shakespeare, 2000: s. 123) cümleleriyle Türkçeye aktarılmıştır ve herhangi bir anlam bozucu eğilim bulunamamıştır. Ancak EM2'de bu cümle "Kıralımızın sefere çıktı̆̆ı gece" (Shakespeare, 1967: s. 118) cümlesiyle aktarılmış ve geçmiş zaman kullanılarak olay sadece bir defa gerçekleşmiş anlamına gelmektedir. EM4’te de "Kralımızın sefere çıktı̆̆ı geceydi" (Shakespeare, 2015: s. 109) cümlesinde olay sadece bir defa yaşanmış ve bitmiş anlamı katmaktadır. Her ne kadar özgün metindeki since göstergesi ve olayın devam etmekte olduğu anlamı yok edilmiş olsa da, EM2 ve EM4'teki söylemler özgün metindeki söylemden izler taşımakla birlikte yanlış bir anlam ortaya çıkmıştır. Bu iki çevirideki durum Öztürk Kasar’ın (Öztürk Kasar ve Tuna, 2015) dizgeselliğine göre anlamın bozulması eğilimi olarak sınıflandırılabilir.

Yükümsüz Özne Söylemi 9:

"LADY MACBETH

Yet here's a spot.

DOCTOR

Hark, she speaks, I will set down what comes from her, to satisfy my remembrance the more strongly. LADY MACBETH

Out damned spot: out I say! One: two: why then 'tis time to do't: Hell is murky. Fie, my Lord, fie, a soldier, and afear'd? What need we fear? who knows it, when none can call our power to accompt: yet who would have thought the old man to have had so much blood in him.

....

Here's the smell of the blood still: all the perfumes of Arabia will not sweeten this little hand. Oh, oh, oh!

DOCTOR

10 Tarafımızdan çevrilmiştir. 
Well, well, well.

GENTLEWOMAN

Pray God it be, sir.

\section{DOCTOR}

This disease is beyond my practise: yet I have known those which have walk'd in their sleep, who have died holily in their beds."

(Shakespeare, 1994: s. 94).

Bu söylemde, bir önceki örnekte Lady Macbeth’i görmeye gelen doktor, Lady Macbeth'in uyurgezer bir anına rastlamıştır. Lady Macbeth’in tüm söylemleri uyurgezer durumda üretilmiştir. Lady Macbeth korku, endişe ve üzüntü gibi tutkular kökenli içkin bileşenin güdümünde bu patolojik rahatsızlığa yakalanmıştır. Lady Macbeth'in uyurgezerken bu söylemleri ürettiğini, doktorun "This disease is beyond my practise" (Shakespeare, 1994: s. 94) [Bu hastalık benim uzmanlığımı aşar ${ }^{11}$ cümlesinden anlaşılmaktadır. Ayrıca doktorun "walk'd in their sleep" [uykularında gezinenler ${ }^{12}$ ] söylemi de bunu doğrulamaktadır. Lady Macbeth'in "Here's the smell of the blood still: all the perfumes of Arabia will not sweeten this little hand” (ibid, s. 94) [Kan kokusu halen duruyor: Arabistan'ın tüm güzel kokuları bu küçük eli tatlılaştırmayacak ${ }^{13}$ ] cümlesi korku ve endişe kökenli tutkular türündeki içkin bileşenin bu söylemde söyleyen üstünde etkili olduğunu düşündürmektedir. Öztürk Kasar’nn (2017) yükümsüz özneler sınıflandırmasına göre söyleyen bu söylemde patolojik bir durumdan kaynaklanan bilinç eksikliği konumunda yükümsüz özneye dönüşmüştür. Öztürk Kasar (2017) uyurgezerliği patolojik bir durum olarak sınıflandırmıştır. Ayrıca doktorun bunu bir hastalık olarak görmesi de bu sınıflandırmayı doğru çıkarmaktadır. Bu söylemin çevirileri aşağıdadır.

EM1

"LADY MACBETH

Şurada bir leke daha.

HEKIM

Dinleyin! Konuşuyor. Daha iyi hatırlamak için dediklerini yazacağım.

\section{LADY MACBETH}

Çık, melun leke! Çık diyorum! Bir...İki... Eh öyleyse yapmak vakti geldi. Cehennem karanlıkmış. Ayıp size, efendimiz, ayıp! Hem asker olun, hem korkun! Kimin bildiğinden ne çekilelim, nasıl olsa kudretimiz sorgu suale gelmez. Yine de, kim ihtiyarda bu kadar kan bulunacağını zannederdi?

İşte hala kan kokuyor. Arabistan'ın bütün ıtırları şu minicik elin kokusunu tatlılaştırmaz. Ah! Ah! Ah!

$\cdots$

\section{HEKIM}

İyi iyi iyi.

NEDİME

Allah versin de öyle olsun, efendim.

HEKIM

Bu illet benim hekimliğimden öte bir şey. Bununla beraber, uykusunda yürüyüp de sonra dini bütün olarak yatağında ölen insanlar gördüm."

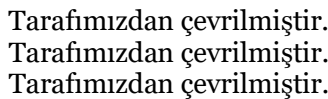


Subjectivity: a step of semiotics of translation and translation evaluation of a play from semiotics of translation point of view / M. Kuleli (p. 33-72)

(Shakespeare, 1946: s. 86-87).

\section{EM2}

\section{"LADY MACBETH}

Bir leke var şurada hala.

\section{HEKIM}

Konuşuyor, dinleyelim.

Yazayım söylediklerini tam hatırlamak için.

\section{LADY MACBETH}

Çık elimden, korkunç leke çık diyorum sana!

Bu bir... Bu iki... Tamam: Haydi şimdi.

Cehennem ne karanlıkmış!

Yazık, koca kıralım benim.

Yazıklar olsun! Bir asker korkar mı hiç?

Ne diye korkuyorsun bilinmesinden?

Kimin haddine bizden hesap sormak?

Bir ihtiyardan bu kadar kan akacağı kimin aklına gelirdi?

…

Kan kokuyor hala şurası:

Arabistanın bütün kokuları

Temizliyemiyecek şu ufacık eli!

Of! Yeter artık! Yeter!

\section{HEKIM}

Kötü, kötü, kötü...

\section{KADIN}

Allah iyi eder inşallah!

\section{HEKIM}

Benim hekimliğimi aşıyor bu hastalık;

Ben ki uykuda yürüyen nice hastalara baktım

Ve hepsi rahat döşeklerinde dindarca öldü.”

(Shakespeare, 1967: s. 120-122).

$\mathrm{EM}_{3}$

\section{"LADY MACBETH}

İşte gene bir leke!

\section{DOKTOR}

Dinle, konuşuyor. Söylediklerini yazayım da hatırlamak kolay olsun.

\section{LADY MACBETH}


Hadi çık, uğursuz leke, çıksana! Bir, iki. Tamam, işi bitirme vakti geldi. Cehennem çok kasvetli. Ayıp, Lordum, ayıp! Asker korkar mı? Anlarlarsa anlasinlar; kimin haddine yetkimizi sorgulamak? Ama hayret, ihtiyarda da amma bitmez kan varmış; kimin aklına gelirdi?

Elim hala kan kokuyor. Arabistan’n tüm esansları yetmez bu küçük eli güzel kokutmaya. Ah! Ah! Ah!

\section{DOKTOR}

Vay, vay, vay!

\section{NEDIME}

İnşallah bir şeyi yoktur efendim!

\section{DOKTOR}

Ben bu hastalı̆̆a bir şey yapamam. Ama, uykusunda yürüyüp de, sonunda huzur içinde döşeğinde ölen insanlar da tanıdım."

(Shakespeare, 2000: s. 124-125).

$\mathrm{EM}_{4}$

\section{"LADY MACBETH}

Hala bir leke var şurada.

\section{HEKIM}

Konuşuyor, dinleyelim. Hatırlamak için bunları bir bir yazmalıyım.

\section{LADY MACBETH}

Çık elimden lanetli leke! Çık diyorum sana! Biri bu, ikincisi şu. Öyleyse yapmanın tam vakti. Cehennem kapkaranlıkmıș. Yazıklar olsun lordum, utanın! Hiç asker adam korkar mı? Ne diye korkuyorsun bilinmesinden? Bizden hesap sormak kimin haddine? Bir ihtiyardan bu kadar kan akacağı kimin aklına gelirdi?

Hala kan kokusu var ellerimde. Arabistan’ın bütün kokuları temizleyemez bu ufacık eli. Oof of!

....

\section{HEKIM}

Vay vay vay.

\section{NEDİME}

Dileyelim, Tanrı şifa versin, efendim.

\section{HEKIM}

$\mathrm{Bu}$ illet benim hekimliğimi aşıyor. Ama şunu söyleyeyim, uykuda yürüyenlerin de yataklarında dindarca öldüklerini gördüm.”

(Shakespeare, 2015: s. 110-111).

Doktorun özgün metindeki "well, well, well" söylemi, Lady Macbeth'in söylemlerini ve kendi ne diyeceğini düşünürken ürettiği bir geçiş söylemidir. Oxford Çevrimiçi Sözlüğe göre "well” konuşma dilinde "bir sonraki söyleyeceği şeyleri düşünürken durmak için, bir konuşmayı sürdürmek veya bitirmek için kullanılır" (Oxford Çevrimiçi Sözlük, Erişim tarihi: 16.10.2018). Dolayısıyla çare bulunmaz (beyond my practise) bir hastalığı düşünmek için bir doktorun, "well" göstergesinin ilk anlamı olan "iyi" kelimesini kullanmasını beklenmez. Bu gösterge EM2'de "Kötü, kötü, kötü”; EM3’te "Vay, vay, vay”; EM4’te “Vay vay vay” karşıllğı ile çevrilmiştir ve hastalığın endişe verici olduğunu özgün metin okuru 
Subjectivity: a step of semiotics of translation and translation evaluation of a play from semiotics of translation point of view / M. Kuleli (p. 33-72)

gibi çeviri metin okuruna da yansıtmaktadır. Ancak EM1'de bu gösterge "İyi iyi iyi” olarak çevrilmiştir ve göstergenin potansiyel ancak gerçek metinde gerçekleşmeyen bir anlamı kullanılmıştır. Ancak bu eğilim anlamın kaydırılması olarak düşünülemez çünkü göstergenin özgün metin bağlamındaki anlamının tam tersi çevrilmiştir ve erek metin okuru iyi bir durum yaşanmakta olduğunu düşünmektedir. Öztürk Kasar’nn (Öztürk Kasar ve Tuna, 2015) izegselliğine göre bir göstergenin tam zit anlamıyla çevrilmesi anlamın çarpıtılması eğilimi olarak düşünülebilir.

Yükümsüz Özne Söylemi 10:

"MACBETH

I' gin to be aweary of the sun,

And wish th' estate o' th' world were now undone.

Ring the alarum-bell, blow wind, come wrack,

At least we'll die with harness on our back."

(Shakespeare, 1994: s. 102).

Bu söylemdeki "I gin to be aweary of sun" (Shakespeare, 1994: s. 102)[Güneşten usanmaya başliyorum 14] ve "wish th' estate o' th' world were now undone" (ibid, s. 102) [dünya şimdi yok olsun istiyorum¹5] cümleleri, Birnam ormanının yürüdüğünü (aslında Malcolm ve Macduff liderliğindeki İngiliz askerlerinin kamufle olmak amacıyla ormanın dallarınını üstlerine örterek yürümesi) öğrenen ve hayaletlerin kehanetlerinin gerçekleştiğini gören Macbeth'in derin bir hayal kırıklğ̆ ve endişe içinde ürettiği, kavramlaştırıcı bileşenin etkisinden uzaklaşarak tutkular kaynaklı içkin bileşenin güdümünde yükümsüz özneye dönüştüğü cümlelerdir. Öztürk Kasar’ın (2017) yükümszü özneler sınıflandırmasına göre bu söylemde söyleyen esenliksiz durumda tutkular türündeki içkin bileşenden kaynaklanan bedensel dengesizlik durumunda yükümsüz özneye dönüşmüştür. Bu söylemin çevirileri aşağıdadır.

EM1

"MACBETH

Güneşten bıkmaya başlıyorum artık, dünyanın sonu gelmesini istiyorum. Tehlike çanını çalın! Es, rüzgar! Gelsin yakıp yıkmak! Hiç değilse sırtımızda zırhla ölürüz."

(Shakespeare, 1946: s. 96).

EM2

"MACBETH

Ben güneşi görmekten bezdim artık.

Varsın bütün dünya yok oluversin!

Çalsın bela çanları! Essin ölüm rüzgarları

Zırhımız sırtımızda ölürüz hiç olmazsa!"

(Shakespeare, 1967: s. 134).

EM3

"MACBETH

Tarafımızdan çevrilmiştir.

Tarafımızdan çevrilmiştir. 
Güneşten bıkmaya başladım;

Keşke şu anda evren dağılıp param parça olsa.

Savaş çanlarını çalın! Esin rüzgarlar!

Gel bakalım bela! Hiç değilse,

Sırtımızda zırhımızla ölürüz.”

(Shakespeare, 2000: s. 136).

EM4

"MACBETH

Artık bıkmaya başladım ben bu güneşten,

Evrenin dengesi bozulsun, yok olsun gitsin!

Çalın tehlike çanlarını!

Esip uğuldasın ölüm rüzgarları!

Sırtımızda zırhla ölürüz hiç olmazsa.”

(Shakespeare, 2015: s. 120).

Bu söylemin çevirilerinde, hem gösterge hem de söylem boyutlarında herhangi bir anlam bozucu eğilim bulunamamıştır. Özgün metin okurunun alımladığı yükümsüz öznelik durumu, erek metin okuru tarafından da alımlanabilecek biçimde göstergelerin anlam evreni korunmuştur.

\section{Sonuç ve tartışma}

Özgün metin üzerindeki öznelik dönüşümü odaklı yapılan göstergebilim çözümlemesi sonucunda, 10 söylemde yükümsüz öznelik durumu saptanmıştır. Öztürk Kasar’ın yükümsüz özneler sınıflandırması temel alınarak yapılan sınıflandırma sonucunda, yükümsüz özne içeren 10 söylemin altısında (\%60) söyleyenin esenliksiz durumda tutkular türündeki içkin bileşenden kaynaklanan bedensel dengesizlik durumunda olduğu; ikisinde (\%20) patolojik bir durumdan kaynaklanan bilinç eksikliği durumunda olduğu; birinde (\%10) esenlikli durumda tutkular türündeki içkin bileşenden kaynaklanan bedensel dengesizlik durumunda olduğu; birinde (\%10) bir işleve indirgenmiş kimlik olarak bireysel biçim özne durumunda olduğu bulunmuştur. Coquet'nin (1997; 2007) "Söyleyenler Kuramı" çerçevesinde geliştirdiği ve Öztürk Kasar’ı (2012; 2017) çeviri göstergebilimi dahilinde benimsediği ve derlediği "söyleyenin bileşenleri” incelendiğinde, 10 söylemdeki yükümsüz öznelerin dokuzunda (\%90) tutku kaynaklı içkin bileşenin, birinde (\%10) ise simgesel güçler kaynaklı aşkın bileşenin etkisinde olduğu saptanmıştır. Bu durum, Macbeth oyununun tutkular üzerine tasarlanmış bir metin olduğunu göstermektedir. Ayrıca, kavramlaştırıcı bileşenin etkisinden uzaklaşıp içkin bileşen ve aşkın bileşenin güdümüne giren söyleyenlerin yükümsüz özneye dönüşebileceğini göstermektedir. Shakespeare oyunlarında içkin bileşenin güdümünden kaynaklanan yükümsüz özne söylemleri dikkat çekici bir özellik olarak düşünülebilir. "Antony and Cleopatra oyununda saptanan yükümsüz özneye dönüşen öznelerin çoğunlukla tutkular türündeki içkin bileşenin etkisi altında söylemlerini ürettikleri bulunmuştur" (Öztürk Kasar ve Kuleli, 2016: s. 122). Ayrıca, bunu destekleyen diğer bir bulgu ise "Coriolanus oyunundaki öznelik dönüşümüne neden olarak söyleyeni yükümsüz özne yapan bileşen çoğunlukla tutkular kökenli içkin bileşen olarak bulunmuştur” (Kuleli, 2017: s. 530).

Özgün metinde yükümsüz özne söylemi saptanan 10 söylemin, farklı on ylllarda farklı çevirmenler tarafından yapılan dört Türkçe çevirisi Öztürk Kasar’ın (Öztürk Kasar ve Tuna, 2015) geliştirdiği çeviride 
Subjectivity: a step of semiotics of translation and translation evaluation of a play from semiotics of translation point of view / M. Kuleli (p. 33-72)

anlam bozucu eğilimler dizgeselliğine göre değerlendirilmiştir. Bu değerlendirme sonucunda, dört erek metnin yükümsüz özne söylemlerinin çevirisinde toplam 18 anlam bozucu eğilim bulunmuştur. Bu anlam bozucu eğilimlerin altısı (\%33.33) anlamın bozulması; dördü (\%22.22) anlamın aşırı yorumlanması; üçü (\%16.67) anlamın yok edilmesi; ikisi (\%11.11) anlamın saptırılması; ikisi (\%11.11) anlamın kaydırılması; biri (\%5.56) anlamın çarpıtılması eğilimleri olarak bulunmuştur. Dolayısıyla, yükümsüz özne söyleyeni içeren 10 söylemin dört Türkçe çevirisinde, altı defa özgün metindeki söylem veya göstergelerle ilintisiz olmasa da erek metinde kaynak metne kıyasla yanlış bir anlam biriminin üretildiği; dört defa çevirmenler tarafından özgün metinde üstü kapalı olarak verilmiş göstergelerin apaçık bir şekilde erek metin okurunda yansıtıldığı veya özgün metinde yer almayan gösterge ve anlam birimlerin erek metinde çevirmenler tarafindan kullanıldığı ve böylece erek metinde aşırı bir anlam ortaya çıktığı; üç defa özgün metindeki gösterge veya anlam içeren birimlerin erek metinde okura hiç yansıtılmadığı, yani anlamın metinden silindiği; iki defa özgün metinle tamamen ilintisiz anlamların erek metinde üretilmesiyle ortaya aykırı anlam çıktı̆̆ı; iki defa özgün metindeki bir göstergenin sahip olduğu potansiyel ancak özgün metindeki bağlamında gerçekleşmediği bir anlamının erek metinde üretilerek ortaya başka anlamın çıktığı; bir defa özgün metindeki bir anlam biriminin tam tersinin erek metinde üretildiği ve ortaya karşıt anlam çıktı̆̆ı saptanmıştır. Öztürk Kasar’ın (Öztürk Kasar ve Tuna, 2015) anlam bozucu eğilimlerin anlamlama alanı sınıflandırmasına göre ise, 18 anlam bozucu eğilimden dokuz eğilimin (\%50) göstergenin anlam evreninin sınırlarında dolay anlam ürettiği; beş eğilimin (\%27.78) göstergenin anlam alanının dışında anlamsızlık ortaya çıkardığı; dört eğilimin ise (\%22.22) göstergenin anlam alanı içerisinde anlam ürettiği bulunmuştur. Çeviri değerlendirmesi sonucunda, anlamın bulanklaştırılması, anlamın eksik yorumlanması ve anlamın parçalanması eğilimlerine herhangi bir örnek bulunamamıştır.

Çeviri göstergebilimi, "söylem düzeyinde ...bir okuma modeli olarak anlam üreten stratejilerin yeniden üretilmesinde okur ve çevirmene; söylemlerarası düzeyde özgün metin ve erek metini karşılaştırmak için çevirmen, editör ve redaktörlere; söylemüstü söylem düzeyinde ... akademik alanda çeviri incelemesi çalışması yapacak olan akademisyenlere" (Öztürk Kasar, 2009: s. 165-166) katkıda bulunacaktır. "Metni okumak için göstergebilimsel çözümleme yöntemlerinden yararlanan çevirmen ... bu yaklaşımla göstergelere karşı seçicilik ve duyarlılık kazanacak, böylelikle dikkat ya da farkındalık eksikliğinden kaynaklanabilecek istem dışı anlam dönüşümlerinden sakınabilecektir” (Tuna, 2016: s. 96). Bu önermeye göre, özgün metin üzerinde yapılacak bir göstergebilimsel çözümleme yazın çevirmeninin hangi göstergelere hangi açıdan yaklaşıp anlamı erek dilde nasıl yeniden üreteceğini şekillendirmesinde bir fayda sağlayacaktır. Buna bir dayanak olarak, "Göstergebilim, çevirmenlerin göstergeleri saptayıp çözümleyerek erek metinde yeniden üretmesine yardımcı olacaktır, bu yüzden yazın çevirisi öğretimine göstergebilimi dahil etmek faydalı olabilir" (Öztürk Kasar ve Tuna, 2017: s. 180). Göstergebilimin çeviri edemine yapabileceği katkıya dair bir bulguya göre "gösterge duyarlığı gelişen ve algılama çakraları açılan çevirmen, içinde işleyecek anlam bozucu eğilimleri de büyük ölçüde bertaraf edecektir" (Öztürk Kasar ve Tuna, 2015: s. 477). Her ne kadar kimi anlam bozucu eğilimler özgün metindeki göstergenin anlam evreninin dışına çıkarabilme ile sonuçlanabilse de, anlam bozucu eğilimler sadece sonsuza dek kaçılabilecek durumlar olarak görülmemelidir. Ricoeur'a (2008) göre her çeviride anlam kayıpları olacaktır. Ancak, anlam bozucu eğilimleri bilen bir yazın çevirmeni, hem bu eğilimlerden kaçınabileceği durumları bilebilir hem de özgün metin kültürü ve erek metin kültürü arasındaki uyuşmazlıktan kaynaklanabilecek çeviri sorunlarını bu anlam bozucu eğilimlerle nasıl aşabileceğeni görebilir. Bu çalışmada çözümlenen metin bir tiyatro metni olsa da, hem yükümsüz özne sınıflandırması hem de çeviri değerlendirmesi sahne almak üzere değil, edebi amaçlı yapılan çeviri olarak ele alınmıştır. "Tiyatro metinlerinin çevirisi ... sahnelenmek üzere yapılabilir ... ama aynı zamanda edebi amaçlı da yapılabilir" (Karantay, 1995: s. 109-114). Bu çalışmayı genişletmek amacıyla, 
sahne sanatları bakımından ele alınarak yapılan çeviriler de tiyaro göstergebilimi ve çeviri göstergebilimi ışı̆̆ında çözümlenebilir. Ayrıca edebi amaçlı yapılmış bir çeviri ile sahne sanatı amaçlı yapılmış bir çeviri de karşılaştırılarak skopos kuramı temelinde anlam bozucu eğilimler çözümlenebilir.

\section{Kaynakça}

Brooke, N. (Ed.). (2008). Introduction. The Oxford Shakespeare-Macbeth. (ss. 1-81). New York: Oxford University Press.

Coquet, J. C. (1997). La quete du sens: Le langage en question. Paris: PUF.

Coquet, J.-C. (2007). Phusis et logos: Une phénoménologie du langage. Paris: PUF.

Coquet, J.-C. ve Öztürk Kasar, S. (2003). Söylem, göstergebilim ve çeviri. İstanbul: Yıldız Teknik Üniversitesi.

Eco, U. (1978). Semiotics: A discipline or an interdisciplinary method? T.A. Sebeok (Ed.), Sight, sound and taste (ss. 73-83). Bloomington: Indiana University Press.

Frawley, W. (1984). Prolegomenon to a theory of translation. W. Frawley (Ed.), Translation, literary, linguistic and philosophical perspectives (ss. 159-175). Newark: University of Delaware Press.

Hansen, W. ve Hansen, W.F. (2005). Classical Mythology: A guide to the mythical world of the Greeks and Romans. New York: Oxford University Press.

Hawkes, T. (1977). Structuralism and semiotics. London: Routledge.

Hodge, R. (1988). Social semiotics. New York: Cornell University Press.

Karantay, S. (1995). Tiyatro çevirisi: Oyun dili ve çeviri. M. Rifat (Ed.), Çeviri ve çeviri kuramı üstüne söylemler (ss. 93-115). İstanbul: Düzlem Yayınları.

Kuleli, M. (2017). Analysis of subjectivity in literary translation from semiotics of translation point of view: Analysis of subjectivity in the play Coriolanus and translation evaluation. Turkish StudiesInternational Periodical for the Languages, Literature and History of Turkish or Turkic, 12(22), 511-532. doi: http://dx.doi.org/10.7827/TurkishStudies 12372.

Ludskanov, A. (1975). A semiotics approach to the theory of translation. Languages Sciences, 35, 5-8.

Mick, D.G. (1986). Consumer research and semiotics: Exploring the morphology of signs, symbols, and significance. Journal of Consumer Research, 13(2), 196-213. doi: https://doi.org/10.1086/209060.

Morris, C. (1938). Foundations of the theory of signs. O. Neurath, R. Carnap ve C. Morris (Ed.), International encyclopedia of unified science (ss.77-138). Chicago: University of Chicago Press.

Nöth, W. (1995). Handbook of semiotics. Bloomington: Indiana University Press.

Oxford Çevrimiçi Sözlük. https://en.oxforddictionaries.com/definition/well. Erişim tarihi: 16.10.2018.

Öztürk Kasar, S. (2009). Pour une sémiotique de la traduction. C. Laplace, M. Lederer and D. Gile (Ed.), La traduction et ses méiters (ss. 163-175). Caen: Lettres Modernes Minard, Coll. "Champollion $12 "$.

Öztürk Kasar, S. (2012). Jean-Claude Coquet ile bir dil görüngübilimine doğru. XII. Uluslararası Dil, Yazın ve Deyişbilim Sempozyumu Bildiriler Kitabı, ss. 427-433. Edine: Trakya University.

Öztürk Kasar, S. (2017). Jean-Claude Coquet ve söyleyenler göstergebilimi. İ.O. Ayırır, E. Korkut (Ed.), Prof. Dr. Ayşe Eziler Kiran'a armağan (ss. 183-199). Ankara: Hacettepe Üniversitesi Yayınları.

Öztürk Kasar, S. ve Kuleli, M. (2016). Antony and Cleopatra oyununun göstergebilimsel çözümlemesi ve çeviri göstergebilimi bakış açısıyla Türkçe çevirilerinin değerlendirilmesi. RumeliDE-Dil ve Edebiyat Araştırmaları Dergisi, 5, 98-123.

Öztürk Kasar, S. ve Tuna, D. (2015). Yaşam, yazın ve yazın çevisiri için gösterge okuma. Frankofoni Fransız Dili ve Edebiyatı İnceleme ve Araştırmaları Ortak Kitabı, 27, 457-482. 
Öztürk Kasar, S. ve Tuna, D. (2017). Shakespeare in three languages: reading and analyzing sonnet 130 and its translations in light of semiotics. International Journal of Languages' Education and Teaching, 5(1), 170-181. doi: 10.18298/ijlet.1723.

Petrilli, S. (2007). Interpretive trajectories in translation semiotics. Semiotica, 163, 311-345.

Ricoeur, P. (2008). Çeviri üzerine. (S. Öztürk Kasar, Çev.) İstanbul: YKY.

Saussure, F. (2001). Genel dilbilim dersleri. (B. Vardar, Çev.) İstanbul: Multilingual Yabancı Dil Yayınları.

Shakespeare, W. (1946). Macbeth. (O. Burian, Çev.) Ankara: Milli Eğitim Basımevi.

Shakespeare, W. (1967). Macbeth. (S. Eyüboğlu, Çev.) İstanbul: Remzi Kitabevi.

Shakespeare, W. (1994). Macbeth. London: Penguin Books.

Shakespeare, W. (2000). Macbeth. (B. Bozkurt, Çev.) İstanbul: Remzi Kitabevi.

Shakespeare, W. (2015). Macbeth. (Ö. Nutku, Çev.) İstanbul: Mitos Boyut.

Shakespeare, W. (2017). Macbeth. (S. Eyüboğlu, Çev.) İstanbul: Türkiye İş Bankası Kültür Yayınları.

Siskin, J. (1987). A medieval semiotics of translation. Semiotica, 63(1-2), 129-142.

Suhor, C. (1992). Semiotics and the English language arts. Language Arts, 69(3), 228-230.

Torop, P. (2001). The possible fate of the semiotics of translation. Interlitteraria, 6, 46-62.

Torop, P. (2008). Translation and semiotics. Sign Systems Studies, 36(2), 253-257.

Tuna, D. (2016). Çevirmek için çözümlemek: Bel Kaufman'ın Sunday in the Park başlıklı öyküsünde anlam arayış1. Rumeli DE Journal of Language and Literature Studies, 5, 76-97. doi: 10.29000/rumelide.336479.

Tuna, D. ve Kuleli, M. (2017). Çeviri göstergebilimi çerçevesinde yazınsal çeviri için bir metin çözümleme ve karşılaştırma modeli. Konya: Eğitim Yayınevi.

Valseiner, J. ve Gertz, S. K. (2007). Semiotic explorations into cultural worlds: an interdisciplinary synthesis. S.K. Gertz, J. Valsiner ve J. Breaux (Ed.), Semiotics rotations: Modes of neanings in cultural worlds (ss. 197-218). Charlotte, NC: Information Age Publishing. 